\title{
Pendekatan Pluralisme Hukum dalam Studi Hukum Adat: Interaksi Hukum Adat dengan Hukum Nasional dan Internasional
}

\author{
Sartika Intaning Pradhani \\ Fakultas Hukum Universitas Gadjah Mada \\ sartika@mail.ugm.ac.id
}

\begin{abstract}
Scientific study on adat law starts from empirical research, which finds that adat law does not stand alone but works together with other legal orders. This paper is written based on normative legal research by collecting secondary data to answer (1) how legal pluralism explains adat law and adat law community; and (2) how the application of legal pluralism approach in adat law study. The legal pluralism approach explains adat law not as an isolated/marginalized legal order but as a dynamic legal order which interacts with national and international law. From the perspective of legal pluralism, the adat law community is a semi-autonomous social field that produces rules from the interplay between the adat law community and other legal communities/institutions. Categorization of legal pluralism approach application are as follow: first, weak legal pluralism where state law recognizes adat law either by law and regulation or court decision; second, strong legal pluralism which describes through the semiautonomous social field, shopping forum, and forum shopping concept; third, legal pluralism multi-sited which explain the relationship between legal phenomena in local, national, and international level; and elaborate the role of information, communication, and technology which bridges legal phenomenon from one to another.
\end{abstract}

Keywords: legal pluralism; adat law; semi-autonomous social field; legal interaction. 


\section{Abstrak}

Kajian ilmiah terhadap hukum adat berangkat dari penelitian lapangan yang menemukan bahwa hukum adat tidak pernah berdiri sendiri dan selalu berinteraksi dengan tertib hukum yang lain. Artikel ini ditulis berdasarkan penelitian hukum normatif dengan mengumpulkan data sekunder berupa laporan-laporan penelitian dan artikel jurnal untuk untuk menjawab (1) bagaimana pendekatan pluralisme hukum menjelaskan hukum adat dan masyarakat hukum adat; dan (2) bagaiamana pendekatan pluralisme hukum digunakan dalam studi hukum adat hari ini. Pendekatan pluralisme hukum memahami hukum adat tidak sebagai suatu ketertiban hukum yang terpisah atau termarginalisasi dari ketertiban hukum yang lain, tetapi secara dinamis terus berinteraksi dengan hukum nasional maupun internasional. Dari perspektif pluralisme hukum, masyarakat hukum adat merupakan suatu wilayah sosial semi otonom yang melahirkan hukum berdasarkan hubungan saling memengaruhi dengan masyarakat hukum lain. Penerapan pendekatan pluralisme hukum dalam studi hukum adat dapat dikelompokkan dalam tiga kategori. Pertama, pluralisme hukum lemah di mana negara mengakui hukum adat baik melalui peraturan perundangundangan maupun putusan pengadilan. Kedua, pluralisme hukum kuat yang dideskripsikan melalui konsep wilayah sosial semi-otonom, forum shopping, dan shopping forum. Terakhir, pluralisme hukum multi-sited yang digunakan untuk menjelaskan hubungan berbagai fenomena hukum antara hukum adat (lokal), nasional, dan internasional serta peran teknologi informasi dan komunikasi dalam menjembatani hubungan tersebut.

Kata kunci: pluralisme hukum; hukum adat; wilayah sosial semi-otonom; interaksi hukum.

\section{A. Pendahuluan}

Artikel ini berusaha menjelaskan pendekatan pluralisme hukum dalam memahami hukum adat dan masyarakat hukum serta penerapannya dalam studi hukum adat. Pendekatan pluralisme hukum memahami hukum adat sebagai suatu ketertiban hukum yang dinamis karena terus berinteraksi dengan ketertiban hukum lain baik di level nasional maupun internasional. Pendekatan ini melihat masyarakat hukum adat sebagai wilayah sosial semi otonom yang melahirkan hukum sebagai hasil hubungan saling memengaruhi 
antara fungsionaris hukum adat dan juga para anggota masyarakat hukum adat dengan institusi hukum dan anggota masyarakat hukum yang lain. Dalam kajian hukum adat, interaksi hukum adat dengan hukum negara dijelaskan dengan pluralisme hukum lemah dan pluralisme hukum kuat, serta saat ini ada juga pluralisme hukum yang menjelaskan hubungan antara hukum adat dan hukum internasional.

Studi empiris terhadap hukum adat tidak melihat realitas hukum adat sebagai hukum yang berdiri sendiri, namun selalu berinteraksi dengan tertib hukum lain. Kajian ilmiah terhadap hukum adat berangkat dari penelitian lapangan yang mendokumentasikan pandangan hidup dan perilaku-perilaku masyarakat sejak zaman Hindia Belanda hingga saat ini. Meskipun pendekatan pluralisme hukum dalam kajian hukum adat telah dikenal sejak hukum adat dikaji secara ilmiah, dalam perjalanannya pengajaran hukum adat lebih didominasi dengan pendekatan hukum adat positivistik dan menjauhkan hukum adat dari realitas empirisnya.

Laporan penelitian lapangan terhadap fenomena hukum adat dapat ditelusuri sejak 1886-1889 ketika Liefrinck mencatat tentang hukum tanah pribumi di Bali Utara, termasuk hak-hak atas tanah yang tidak diolah dan pajak bumi para raja. ${ }^{1}$ Kemudian pada 1891 , Wilken mendokumentasikan hubungan antara kebiasaan rakyat dan agama rakyat yang dipengaruhi oleh Islam atau Hindu. ${ }^{2}$ Pada tahun yang sama, Hurgronje menuliskan tentang berbagai macam tertib hukum yang berlaku di Aceh, yaitu hukum para raja, hukum Islam, dan hukum adat. ${ }^{3}$ Berdasarkan pendapat Hurgronje, Van Vollenhoven mengkonstruksi bahwa hukum yang berlaku bagi pribumi terdiri dari hukum adat pribumi, yaitu indigenous law yang telah dipengaruhi oleh elemen-elemen agama, dan hukum kodifikasi. ${ }^{4}$

1 C. van Volenhoven, Penemuan Hukum Adat (Jakarta: Penerbit Djambatan, cetakan kedua, 1987), hlm. 130-31.

2 Volenhoven, Penemuan Hukum Adat, hlm. 130-31.

3 C. Snouck Hurgronje, The Achehnese Vol. I., terj. A.W.S. O'Sullivan (Leyden: Late E.J. Brill,1906), hlm. 16.

4 C. van Vollenhoven, Van Vollenhoven on Indonesian Adat Law Selection from Het Adatrecht Van Nederlandsch-Indie (Volume I, 1918; Volume II, 1931), ed. J. F. 
Sebagaimana ditunjukkan oleh Hurgroje dan Van Vollenhoven, hukum tidak semata-mata berasal dari hukum negara. Secara empiris, hukum Hindia Belanda mengalami persinggungan ketertiban hukum dengan, baik hukum negara, hukum para raja, hukum agama, dan hukum adat. Benda-Beckmann dan Benda-Beckmann berpendapat bahwa Van Vollenhoven memperkenalkan istilah hukum adat tidak untuk membedakan adat berakibat hukum dan tidak berakibat hukum, tetapi untuk menunjukkan ada realitas keteraturan hidup bersama yang berasal dari legitimasi yang berbeda dari hukum negara atau saat ini disebut sebagai pluralisme hukum. ${ }^{5}$

Pengertian dan cakupan kajian pluralisme hukum terus berkembang untuk menjelaskan berbagai fenomena hukum. Moore mengamati bahwa lapangan sosial sebagai subjek kajian hukum merupakan suatu lapangan yang semi-autonomous karena dalam lapangan tersebut berbagai ketertiban hukum saling berkompetisi, berkolaborasi, dan bertukar untuk membentuk suatu hubungan dan aturan dengan sanksi yang efektif. ${ }^{6}$ Griffiths mengatakan bahwa pluralisme hukum merupakan ko-eksistensi lebih dari satu keteraturan hukum dalam suatu lapangan sosial dan mengklasifikasikan pluralisme hukum dalam pluralisme hukum lemah dan kuat. ${ }^{7}$

Pasca-Griffith, pluralisme hukum tidak lagi dipandang sebagai pendekatan yang dapat secara tegas memisahkan satu ketertiban hukum dengan ketertiban hukum lain karena, sebagaimana disampaikan Santos, pluralisme hukum merupakan konsep kunci dalam pandangan postmodern terhadap hukum di mana berbagai konsep hukum yang berbeda tumpang tindih, saling menembus dan

Holleman (Leiden: KITLV, 1981), hlm. 5.

5 Franz von Benda-Beckmann dan Keebet von Benda-Beckmann, "Myths and Stereotypes about Adat Law: A Reassessment of Van Vollenhoven in the Light of Current Struggles over Adat Law in Indonesia”, Bijdragen tot de Taal-, Land-en Bolkenkunde, 168, 2 / 3 (2011), hlm. 171.

6 Sally Falk Moore, "Law and Social Change: the Semi-Autonomous Social Field as An Appropriate Subject of Study", Law and Society Review, 7, 4 (1972), hlm. 744.

7 John Griffiths, "What is Legal Pluralism?", Journal of Legal Pluralism and Unofficial Law, 24, 2 (1986), hlm. 1 \& 5-6. 
bercampur dalam pikiran dan perilaku manusia. ${ }^{8}$ Irianto mengatakan bahwa pendekatan pluralisme hukum hari ini tidak hanya untuk mapping of legal universe, tetapi lebih untuk menjelaskan hukum yang bergerak dalam ranah globalisasi dan glokalisasi. ${ }^{9}$ Menurut BendaBeckmann, dkk., pluralisme hukum menjelaskan proses globalisasi dan glokalisasi melalui analisis terhadap mobilitas hukum dan aktor. ${ }^{10}$

Pendekatan pluralisme hukum relevan untuk menjelaskan fenomena hukum adat karena sejak hukum adat menjadi suatu kajian ilmiah, hukum adat selalu berinteraksi dengan keteraturan hukum lain, sehingga tidak mungkin secara tegas membedakan antara hukum adat dan hukum agama atau menarik garis batas yang tegas antara hukum adat dan hukum negara. Mobilitas hukum adat dengan tertib hukum lain membentuk sintesis hukum baru dapat ditunjukkan dalam ilustrasi-ilustrasi berikut. Peribahasa Minangkabau yang mempertemukan hukum adat dan hukum Islam, adat basandi syarak syarak basandi kitabullah, saat ini diadopsi dalam rencana pembangunan jangka menengah daerah Sumatera Barat 2016-2021. ${ }^{11}$ Konsep Tri Hita Karana masyarakat tradisional Bali tidak hanya menjadi tradisi masyarakat tersebut karena ikut berkembang dengan perkembangan politik pemerintahan daerah. ${ }^{12}$ Putusan pengadilan

8 Boventura de Sausa Santos, "Law: A Map of Misreading towards a Postmodern Conception of Law”, Journal of Law and Society, 14, 3 (1987), hlm. 297-98.

9 Sulistyowati Irianto, "Pluralisme Hukum dalam Perspektif Global", dalam Kajian Sosio-Legal, ed. Adrian W. Bedner, dkk. (Denpasar \& Jakarta: Pustaka Larasan, Universitas Indonesia, Universitas Leiden, Universitas Groningen, 2012), hlm. 157.

10 Franz von Benda-Beckmann, Keeben von Benda-Beckmann, dan Anne Griffiths, "Mobile People, Mobile Law: An Introduction", Mobile People, Mobile Law Expanding Legal Relations in a Contracting World, ed. dalam Franz von Benda-Beckmann, Keeben von Benda-Beckmann, dan Anne Griffiths (Burlington: Ashgate Publishing Company, 2005), hlm. 1-4.

11 Asrinaldi dan Yoserizal, "Problems with the Implementation of Adat BasandiSyarak Syarak Basandi Kitabullah Philosophy”, Masyarakat, Kebudayaan dan Politik, 33, 2 (2020), hlm. 162-73.

12 Dik Roth dan Gede Sedana, "Reframing Tri Hita Karana: From 'Balinese Culture' to Politics”, The Asia Pacific Journal of Anthropology, 16, 2 (2015), hlm. 157-75. 
negara mengakui dan kadang mengubah ketentuan hukum adat dalam kasus-kasus konkret. ${ }^{13}$ Hak-hak masyarakat hukum adat diakui dalam berbagai peraturan perundang-undangan di berbagai level pemerintahan dan juga dalam putusan pengadilan. ${ }^{14}$

Mobilitas hukum adat terjadi karena ada mobilitas aktor. Mobilitas aktor yang kemudian menyebabkan hukum adat bergerak

13 Lihat Sartika Intaning Pradhani, "Perspektif Pemikiran Hukum Barat dalam Penemuan Hukum Adat oleh Hakim: Studi Kasus Putusan Sengketa Tanah Adat di Pengadilan Negeri Muara Teweh, Padang, Makale, dan Painan”, Bhumi: Jurnal Agraria dan Pertanahan, 6, 1 (2020): 1-14; Mercy M. M. Setlight, "Penerapan Hukum Pidana Adat dalam Putusan Pengadilan di Wilayah Pengadilan Negeri Tahuna”, Lex et Societatis, 3, 4 (2015): 154-66; Tody Sasmitha JiwaUtama dan Sandra Dini Febri Aristya, "Kajian tentang Relevansi Peradilan Adat terhadap Sistem Peradilan Perdata Indonesia”, Mimbar Hukum, 27, 1 (2015): 57-67; Ilham Abbas, dkk., "Hak Penguasaan Istri terhadap Mahar Sompa Perkawinan Adat Bugis Makassar (Kajian Putusan PA Bulukumba Nomor 45/Pdt.G/2011/PABlk)”, Kanun Jurnal Ilmu Hukum, 20, 2 (2018): 203-18; Jaja Ahmad Jayus, "Eksistensi Pewarisan Hukum Adat Batak Kajian Putusan Nomor 1/PDT.G.2015/PB.Blg dan Nomor 439/PDT / 2015 / PT-Mdn”, Jurnal Yudisial, 12, 2 (2019): 235-53; Laila M Rasyid, "Pengakuan terhadap Hukum Adat dalam Kajian Putusan Kasus Tanah Hibah Adat di Pengadilan Sigli”, Riau Law Journal, 1, 1 (2017): 6172; Masril dan Ade Kosasih, "Keberlakukan Asas Ne Bis in Idem terhadap Putusan Pengadilan Adat dalam Tata Hukum Indonesia”, Al-Imarah: Jurnal Pemerintahan dan Politik Islam, 4, 1 (2019): 49-56; Laila M Rasyid, "Penerapan Norma Adat Terang dan Tunai dalam Praktek Peradilan Perdata (Kajian Putusan Pengadilan Nomor 23/Pdt.G/2013/PN.Bj), Jurnal Ilmu Hukum Reusam, 7, 2 (2019): 1-14.

14 Rikardo Simarmata, "The Enforceability of Formalised Customary Land Rights in Indonesia”, Australian Journal of Asian Law, 19, 2 (2019): 1-15; Jacqueline Vel, Yando Zakaria, Adriaan Bedneer, "Law-Making as a Strategy for Change: Indonesia's New Village Law, Asian Journal of Law and Society, 4, 2 (2017): 1-25; Maria Rita Roewiastoeti, "Dampak Sosial Politik Putusan Mahkamah Konstitusi Nomor 35/PUU-X/2012”, Wacana, 16, 33 (2014): 49-59; R. Yandi Zakaria, "Kritik Masyarakat (Hukum) Adat dan Potensi Implikasinya terhadap Perebutan Sumberdaya Hutan Pasca-Putusan MK Nomor 35/PUU-X/2012: Studi Kasus Kabupaten Kutai Barat, Kalimantan Timur”, Wacana, 16, 33(2014): 99-135; Maria S. W. Sumardjono, Pluralisme Hukum Sumber Daya Alam dan Keadilan dalam Pemanfaatan Tanah Ulayat (Yogyakarta: Fakultas Hukum Universitas Gadjah Mada, 2018), hlm. 1135; Ahmad Redi, Yuwono Prianto, Tundjung Herning Sitabuana, dan Ade Adhari, "Konstitusionalitas Hak Ulayat Masyarakat Hukum Adat atas Hak Ulayat Rumpondi Provinsi Lampung”, Jurnal Konstitusi, 14, 3 (2017): 46388 . 
dan berubah dapat dilihat dalam ilustrasi tulisan-tulisan berikut. Dalam disertasinya, Irianto menggambarkan bagaimana anak perempuan dan janda menjadi aktor dalam perubahan hukum waris Batak melalui berbagai strategi, baik dengan menempuh jalur litigasi maupun non-litigasi dengan berbagai pertimbangan. ${ }^{15}$ Misionaris Kristen juga berpengaruh terhadap perkembangan hukum adat. Barnes menulis bagaimana pengaruh misionaris Kristen terhadap perkembangan hukum adat Lamalera. ${ }^{16}$ Bemmelen dan Grijns juga menyampaikan pengaruh misionaris Kristen dan tokoh agama Islam serta aparat penegak hukum negara terhadap praktik kawin anak yang terjadi di Tapanuli Utara dan Sukabumi. ${ }^{17}$ Lembaga Swadaya Masyarakat baik dalam level lokal, nasional maupun internasional juga berpengaruh terhadap gerakan resistensi masyarakat hukum adat sebagaimana digambarkan oleh Ginting dan Espinosa dalam gerakan perlawanan masyarakat hukum adat Malind terhadap proyek Merauke Integrated Food and Energy Estate. ${ }^{18}$

Tidak hanya aktor yang terus bergerak yang menjadi fokus kajian pluralisme hukum, tetapi juga aktor yang diam dan menjadi recipient yang berinteraksi dengan aktor yang bergerak. Hal ini digambarkan oleh Siscawati tentang bagaimana perempuan adat Kasepuhan Banten Kidul, Ibu Asih, menanggapi aktor-aktor yang membawa hukum yang bergerak untuk memperluas areal Taman Nasional Gunung Halimun. ${ }^{19}$ Simbolon juga mendeskripsikan bagaimana

15 Sulistyowati Irianto, Perempuan di antara Berbagai Pilihan Hukum (Studi mengenai Strategi Perempuan Batak Toba untuk Mendapatkan Akses kepada Harta Waris melalui Proses Penyelesaian Sengketa) (Jakarta: Yayasan Pustaka Obor Indonesia, 2012), hlm. 146-274.

16 R. H. Barnes, "A Catholic Mission and the Purification of Culture: Experience in An Indonesia Community”, JASO, 23, 2 (1992): 169-80.

17 Sita Thamar van Bemmelen dan Mies Grijns, "Relevansi Kajian Hukum Adat: Kasus Perkawinan Anak dari Masa ke Masa”, Mimbar Hukum, 30, 3 (2018): 516-43.

18 Wiranta Yudha Ginting dan Cristina Espinosa, "Indigenous Resistance to Land Grabbing in Mereauke, Indonesia: The Importance and Limits of Identity Politics and the Global-Local Coalitions", International Journal of Social Science and Business, 1, 3 (2016): 1-14.

19 Mia Siscawati, "Pertaruangan Penguasaan Hutan dan Perjuangan Perempuan Adat”, Wacana, 16, 33 (2014): 167-77. 
Dolok Marlalitali, Sugapa dan Parbulun terdampak dan bereaksi terhadap proses privatisasi tanah dalam kerangka hukum negara. ${ }^{20}$

Berdasarkan pemaparan tersebut, pendekatan pluralisme hukum dalam studi hukum adat bukan merupakan suatu perspektif yang baru. Namun demikian, dalam studi hukum adat, pluralisme hukum tidak diajarkan sebagai cara untuk melihat realitas fenomena hukum adat. Studi hukum adat, sebagaimana disampaikan Simarmata, lebih fokus pada pendekatan hukum adat positivistik dan sebagai akibatnya menjauhkan hukum adat dari realitas empirisnya. ${ }^{21}$ Kebaruan dari tulisan ini adalah tidak hanya mendeskripsikan pendekatan pluralisme dalam memahami hukum adat dan masyarakat hukum adat, tetapi juga menunjukkan bagaimana pendekatan pluralisme diterapkan dalam studi-studi hukum adat. Penerapan pendekatan pluralisme hukum dalam studi hukum adat tidak sebatas pada hubungan antara hukum adat dan hukum negara, tetapi juga dengan hukum internasional.

Artikel ini ditulis berdasarkan data sekunder berupa laporanlaporan penelitian dan artikel jurnal. Dalam membahasnya, artikel ini setelah bagian ini terlebih dahulu menguraikan hukum adat dalam bingkai pluralisme hukum. Bahasan ini dimaksudkan untuk menjelaskan bahwa perspektif pendekatan pluralisme hukum tidaklahmemahamihukum adat sebagai suatuketertiban hukum yang terisolasi, melainkan terus berinteraksi secara dinamis dengan tertib hukum lain. Bagian berikutnya membahas masyarakat hukum adat sebagai wilayah sosial semi otonom. Setelahnya, bahasan dilanjutkan dengan penerapan pendekatan pluralisme hukum dalam studi hukum adat, yang dimaksudkan untuk melihat interaksi hukum adat dengan hukum nasional dan internasional. Artikel ditutup dengan kesimpulan yang menjawab pertanyaan bagaimana pendekatan pluralisme hukum menjelaskan hukum adat dan masyarakat hukum

20 Indira Juditka Simbolon, "Peasant Women and Access to Land: Customary Law, State Law and Gender-based Ideology-The Case of Toba Batak (North Sumatera)" (Disertasi, University of Wageningen, Wageningen, 1988), hlm. 219-80.

21 Rikardo Simarmata, "Pendekatan Positivitisk dalam Studi Hukum Adat", Mimbar Hukum, 30, 3 (2018): 465-89. 
adat, dan bagaimana pula pendekatan pluralisme hukum digunakan dalam studi hukum adat hari ini.

\section{B. Memahami Hukum Adat dari Perspektif Pendekatan Pluralisme Hukum}

Pluralisme hukum merupakan suatu proses yang dinamis dan tidak dapat dielakkan. Irianto mengatakan, apa yang disebut sebagai hukum adat berbeda dari apa yang dipikirkan karena dapat terjadi putusan peradilan adat memberikan ruang pada substansi hukum negara dan sebaliknya putusan pengadilan negara mengakui hukum adat. ${ }^{22}$ Fenomena tersebut menunjukkan apa yang dimaksud dengan hukum adat dalam lapangan empirisnya tidak benar-benar dapat dipisahkan dari tertib hukum lain karena hukum adat bekerja dalam suatu lapangan sosial bersama dengan ketertiban hukum lain.

Pendekatanpluralismehukum dalamstudihukumadatberangkat dari realitas bahwa dalam lapangan sosial ko-eksistensi sistem-sistem hukum tidak dapat dibedakan secara jelas batas-batasnya karena sudah terlalu banyak fragmentasi dan tumpang tindih; sehingga batas antara hukum yang satu dan hukum yang lain menjadi tidak jelas. Salah satu realitas lain dari pluralisme hukum hari ini adalah upaya untuk melembagakan hukum adat dalam berbagai peraturan perundang-undangan dengan struktur formal dan logika hukum negara. Menurut Griffiths, pengakuan negara terhadap hukum adat merupakan fenomena pluralisme hukum lemah untuk menciptakan sistem hukum yang paralel di mana sentralisme/kontrol hukum negara tetap menjadi fokus utamanya. ${ }^{23}$

Deskripsi pluralisme hukum lemah dalam kaitannya dengan pengakuan hukum negara terhadap hukum adat juga disampaikan oleh Sumardjono. Menurut Sumardjono, perjumpaan antara hukum

22 Irianto, "Pluralisme Hukum dalam Perspektif Global", hlm. 167.

23 John Griffiths, "Memahami Pluralisme Hukum, Sebuah Deskripsi Konseptual”, dalam Pluralisme Hukum: Sebuah Pendekatan Interdisiplin, ed. Perkumpulan untuk Pembaharuan Hukum Berbasis Masyarakat dan Ekologis (HuMa) (Jakarta: Perkumpulan untuk Pembaharuan Hukum Berbasis Masyarakat dan Ekologis [HuMa], 2005), hlm. 74-80. 
adat dan hukum negara dalam bidang pertanahan merupakan suatu fenomena pluralisme hukumlemahkarena norma hukumadatbersifat komplementer terhadap norma hukum negara; sehingga norma hukum negara tetap dominan. ${ }^{24}$ Selain dalam bidang pertanahan, dominasi hukum negara terhadap hukum adat juga dapat dilihat dalam pengakuan hukum adat dalam Rancangan Undang-Undang Kitab Undang-Undang Hukum Pidana (RUU KUHP) di mana hukum adat hanya sebatas digunakan sebagai landasan untuk menjatuhkan pidana dan tidak digunakan untuk membebaskan atau meringankan pelaku dari sanksi pidana. ${ }^{25}$

Kajian pluralisme hukum dalam studi hukum adat tidak hanya dalam konteks mendeskripsikan hukum adat berinteraksi dengan keteraturan hukum lain dalam suatu lapangan sosial semi-otonom, sebagaimana disampaikan oleh Moore. ${ }^{26}$ Kajian pluralisme hukum dalam studi hukum adat juga dapat diamati dalam proses penyelesaian sengketa. Dalam proses penyelesaian sengketa ada berbagai macam pilihan hukum dan forum untuk menyelesaikan sengketa. Para pihak akan melakukan seleksi untuk menentukan hukum dan forum mana yang paling tepat sesuai dengan kepentingan pihak tersebut forum shopping). Sebaliknya, tiap-tiap forum penyelesaian sengketa juga melakukan seleksi terhadap kasus-kasus diterima apakah termasuk ke dalam wilayah yurisdiksinya (shopping forum).

Benda-Beckmann mendeskripsikan bagaimana para pihak melakukan forum shopping terhadap berbagai institusi penyelesaian sengketa di suatu desa di Minangkabau dan bagaimana institusi penyelesaian sengketa juga melakukan shopping forum untuk sengketa-sengketa yang diterima. ${ }^{27}$ Irianto melakukan penyelidikan

24 Sumardjono, "Pluralisme Hukum Sumber Daya Alam”, hlm. 2-4.

25 Pusat Kajian Hukum adat 'Djojodigoeno' Fakultas Hukum Universitas Gadjah Mada \& Koalisi Masyarakat Sipik Tolak Living Law dalam RKUHP, Brief Paper: Hukum yang Hidup dalam Rancangan Undang-Undang Kitab Undang-Undang Hukum Pidana (Jakarta: Yayasan Lembaga Bantuan Hukum Indonesia \& Pusat Kajian Hukum Adat 'Djojodigoeno' Fakultas Hukum Universitas Gadjah Mada, 2020), hlm. 8.

26 Moore, "Law and Social Change", hlm. 722.

27 Keebet von Benda-Beckmann, "Forum Shoppping and Shopping Forums: Dispute Processing in A Minangkabau Village in West Sumatera”, Journal of 
terhadap anak perempuan dan janda di masyarakat Batak Toba dalam melakukan pilihan hukum dalam menyelesaikan sengketa hak waris. ${ }^{28}$ Rimawati menggambarkan bagaimana pilihan hukum dari anggota Suku Lio dalam melakukan pemilihan forum untuk menyelesaikan sengketa pelayanan kesehatan. ${ }^{29}$ Dengan menggunakan pendekatan forum shopping dan shopping forum dalam menganalisis penyelesaian sengketa di masyarakat hukum adat, Benda-Beckmann, Irianto, dan Rimawati dapat menunjukkan bahwa ada pluralisme hukum yang bekerja di masyarakat hukum adat. Masyarakat hukum adat secara aktif melakukan pilihan terhadap hukum dan forum penyelesaian sengketa mana yang dirasa paling memungkinkan untuk mendapatkan rasa keadilan.

Dalam perkembangannya, pluralisme hukum juga berusaha menjelaskan hubungan dari fenemona hukum satu dengan fenomena hukum lain. Irianto mengatakan bahwa pluralisme hukum menunjukkan perkembangan kajian terhadap hubungan saling ketergantungan antara berbagai sistem hukum, terutama hukum internasional, nasional, dan hukum lokal. ${ }^{30}$ Kajian yang menghubungkan bahwa ada dampak dari kebijakan internasional terhadap hukum adat dapat dilihat dalam kajian Campbell-Nelson. Menurutnya, konflik sumber daya alam perlu dibaca melalui kacamata kompetisi antarsistem hukum di mana hukum adat yang berabad-abad telah mengatur penggunaan tanah diabaikan oleh sistem negara yang baru lahir. ${ }^{31}$ Campbell-Nelson menjelaskan bahwa resistensi masyarakat hukum adat Mollo terhadap tambang marmer merupakan akibat dari kebijakan nasional yang berpengaruh terhadap kewenangan daerah untuk menerbitkan izin tambang. Kesuksesan masyarakat hukum Mollo dalam menghentikan praktik tambang di wilayahnya juga tidak dapat dipisahkan dari kejadian tumbangnya Orde Baru dan terjadi referendum di Timor Leste; sehingga militer

Legal Pluralism, 13, 19 (1981), hlm. 16.

28 Irianto, Perempuan di antara Berbagai Pilihan Hukum, hlm. 278-94.

29 Rimawati, "Pilihan Hukum Penyelesaian Sengketa”, hlm. 131-42.

30 Irianto, "Pluralisme Hukum dalam Perspektif Global”, hlm. 62.

31 Karen Campbell-Nelson, "Learning Resistance in West Timor" (Disertasi, University Massachusetts Amherst, Armherst, 2003), hlm. 128-29. 
yang biasanya digunakan untuk menghalau para pemrotes fokus untuk mengamankan Timor Leste.

Rerefendum Timor Leste berakibat munculnya negara baru; sehingga hubungan antara Indonesia dan Timor Leste menjadi hubungan internasional. Dampak dari referendum tersebut adalah konflik tapal batas antara Indonesia dan Timor Leste sebagai konflik dalam ranah hukum internasional. Oleh karena masyarakat hukum adat yang tinggal di perbatasan antara Indonesia dan Timor Leste secara sosiologis berasal dari leluhur atau rumah adat yang sama, Kase menunjukkan bahwa fenomena hukum di mana penyelesaian sengketa berbasis adat di perbatasan antara Indonesia dan Timor Leste memasuki ranah baru dalam konteks hukum internasional. ${ }^{32}$

Pluralisme hukum membuat hukum menjadi tanpa batas. Teknologi informasi dan komunikasi merupakan suatu alat yang penting untuk menerobos batas-batas geografis yang menghalangi perjumpaan hukum. Berdasarkan hal tersebut, Benda-Beckmann dkk., menyampaikan bahwa upaya untuk menggali pengetahuan dari masyarakat tidak dapat hanya didapatkan dari hubungan face-to-face, tetapi juga dengan jaringan masyarakat tersebut dengan komunitas lain melalui instrumen teknologi informasi. ${ }^{33}$ Akibatnya, penelitian menjadi multi-sited karena tidak hanya dibatasi oleh wilayah geografis, tetapi lebih untuk mengidentifikasi proses aliran informasi.

Fenomena lokal yang kemudian berkembang menjadi multisited sebagai akibat dari penelusuran terhadap aliran informasi dapat ditemukan dalam tulisan Ginting. Ia menjelaskan bagaimana teknologi informasi dan komunikasi dapat menghubungkan masyarakat hukum adat Malind dengan komunitas internasional dalam gerakan perlawanan terhadap Merauke Integrated Food and Energy Estate. ${ }^{34}$ Merauke Integrated Food and Energy Estate adalah proyek nasional yang melibatkan berbagai perusahaan multinasional dan mulai beroperasi di Indonesia pasca tumbangnya Orde Baru Soeharto. Pembebasan

32 Dhesy A. Kase, Model Penyelesaian Sengketa Internasional Berbasis Hukum Adat (Kupang: Media Centre Publishing, 2018), hlm. 120-33.

33 Benda-Beckmann, dkk., "Mobile People, Mobile Law", hlm. 9.

34 Ginting dan Espinosa, "Indigenous Resistance to Land Grabbing”, hlm. 6. 
lahan untuk proyek ini menyebabkan konflik dengan masyarakat hukum adat Malind dan juga menguatkan kembali gerakan Papua Merdeka. Melalui teknologi informasi dan komunikasi, kampanye gerakan resistensi terhadap Merauke Integrated Food and Energy Estate berjejaring dengan non-governmental organization national dan internasional serta dapat masuk dalam forum-forum internasional dan hadir dalam laporan United Nations Committee on the Elimination of Racial Discrimination, United Nation Commission on Economic, Social and Cultural Rights, dan United Nation Special Rapporteur on the Right to Food.

Berdasarkan pemaparan di atas, pendekatan pluralisme hukum memahami hukum adat tidak sebagai suatu ketertiban hukum yang terisolasi dari ketertiban hukum yang lain. Hukum adat secara dinamis terus berinteraksi dengan tertib hukum lain. Upaya formalisasi hukum adat dalam format hukum negara dan pengakuan hukum negara terhadap hukum adat melalui berbagai peraturan perundang-undangan merupakan salah satu contohnya. Selain itu, pengetahuan tentang apa yang dimaksud dengan hukum adat terus berkembang seiring dengan interaksi para aktor dan masyarakat pengembannya dengan tertib hukum lain. Para aktor secara aktif melakukan seleksi terhadap institusi penyelesaian sengketa untuk memberi tafsir tentang apa yang dimaksud dengan hukum adat dan menerapkan hukum adat sesuai dengan kepentingannya. Masyarakat hukum adat juga berinteraksi dengan masyarakat hukum lain baik secara tatap muka maupun melalui jembatan teknologi untuk saling berkomunikasi. Teknologi memperluas cakupan penyebarluasan pengetahuan tentang hukum adat. Dengan teknologi, pengetahuan hukum adat dapat sampai pada komunitas internasional. Hukum adat juga memasuki ranah hukum internasional dengan adanya kemerdekaan suatu negara. Kemerdekaan suatu negara menciptakan batas antarnegara yang membuat identitas anggota masyarakat hukum adat sebagai satu kesatuan hukum menjadi berbeda kewarganegaraan. Hal tersebut membuat sengketa adat memasuki ruang kompleksitas baru dalam sengketa hukum antarnegara. 


\section{Masyarakat Hukum Adat sebagai Wilayah Sosial Semi Otonom}

Hukum negara tidak hanya mengakui hukum adat, tetapi juga masyarakat pengembannya, yaitu masyarakat hukum adat. Atmaja menggunakan perspektif pluralisme hukum untuk menganalisis pengakuan masyarakat hukum adat melalui peraturan daerah. Menurutnya, perspektif pluralisme hukum dalam pengakuan masyarakat hukum adat melalui peraturan daerah masih sebatas perlindungan terhadap masyarakat hukum adat secara kolektif, namun belum melindungi orang perseorangan termasuk juga mekanisme penyelesaian sengketa antara anggota masyarakat sebagai orang perseorangan dan masyarakat hukum adat sebagai kesatuan kolektif. ${ }^{35}$ Pengakuan negara terhadap masyarakat hukum adat melalui peraturan daerah masih terbatas pada masyarakat hukum adat sebagai kesatuan kolektif. Meskipun realitas empiris menunjukkan dinamika perubahan terhadap pranata kehidupan masyarakat hukum adat, konsep masyarakat hukum adat dalam kajian ilmu hukum adat dan konsep masyarakat hukum adat yang diakui oleh negara saat ini masih belum banyak berubah sejak diperkenalkan oleh Van Vollenhoven sebagai rechtgemeenschappen dengan beschikkingrecht-nya.

Van Volenhoven menerjemahkan rechtgemeenschappen sebagai jural communities yang merujuk pada unit korporasi masyarakat hukum adat terorganisir yang memiliki otonomi hukum khusus berdasarkan fakta bahwa masing-masing mempunyai (1) perwakilan khususyangberwenang; dan(2)property bersama yangkhusus, seperti tanah yang dikuasai. ${ }^{36}$ Ter Haar menerjemahkan rechtgemeenschappen sebagai suatu karakter permanen dari kelompok terorganisir yang memiliki kewenangan sendiri dan properti baik material maupun immaterial atau yang diterjemahkan oleh Hoebel dan Schiller sebagai

35 Gede Marhaendra Wija Atmaja, "Politik Pluralisme Hukum dalam Pengakuan Kesatuan Masyarakat Hukum Adat dengan Peraturan Daerah" (Disertasi, Universitas Brawijaya, Malang, 2012).

36 Vollenhoven, Van Vollenhoven on Indonesian Adat Law, hlm. 43. 
autonomous community (komunitas otonom). ${ }^{37}$

Dalam kajian hukum adat dengan pendekatan pluralisme hukum hari ini, masyarakat hukum adat tidak diposisikan sebagai komunitas otonom sebagaimana disampaikan oleh Van Vollenhoven, Ter Haar, Hoebel dan Schiller; melainkan sebagai semi-autonomous social field (wilayah sosial semi-otonom). Griffith menjelaskan, wilayah sosial semi-otonom merupakan suatu kelompok sosial yang teridentifikasi dan terlibat dalam kegiatan reglementary (hukum) di mana proses perilaku individu dan proses interaksi di dalam dan di antara wilayah semi-otonom memengaruhi efektivitas dari hukum pada lokasi dan waktu tertentu. ${ }^{38}$ Menurut Moore, wilayah sosial semi-otonom didefinisikan dan dibatasai bukan oleh organisasinya, tetapi dari karakteristik proses, fakta di mana dalam wilayah tersebut dapat menciptakan hukum (rules) dan memaksa atau mendorong ketaatan dalam wilayah itu. ${ }^{39}$

Utama berpendapat, masyarakat hukum adat merupakan wilayah sosial semi-otonom karena dapat menghasilkan peraturan, kebiasaan, simbol-simbol bagi internal; memiliki kapasitas untuk membuat hukum dan mendorong serta memaksakan kepatuhan kepada para anggotanya. ${ }^{40}$ Irianto juga menggunakan konsep wilayah sosial semi-otonom untuk mengggambarkan lokasi sosial penelitiannya. Menurut Irianto, masyarakat hukum adat Batak Toba merupakan wilayah sosial semi-otonom karena mempunyai aturan sendiri tentang hal-hal yang berkaitan dengan pewarisan, cara-cara pembagian dan pengelolaan perselisihan yang mungkin terjadi serta

37 Vollenhoven, Van Vollenhoven on Indonesian Adat Law, hlm. 43.

38 Griffiths, "Memahami Pluralisme Hukum", hlm. 114.

39 Moore, "Law and Social Change", hlm. 722.

40 Tody Sasmitha Jiwa Utama, "Masyarakat Hukum Adat: Persekutuan Hukum (Rechtsgemeenschappen) atau Subjek Hukum?”,makalahSimposium Nasional Masyarakat Adat II, diselenggarakan Epistema Institute, Aliansi Masyarakat Adat Nusantara (AMAN), Perkumpulan HuMa, Pusat Kajian Hukum Adat Djojodigoeno Universitas Gadjah Mada, Komisi Nasional Hak Asasi Manusia, Fakultas Hukum Universitas Pancasila, Jaringan Kerja Pemetaan Partisipatif, dan Badan Registrasi Wilayah Adat, di Universitas Pancasila, Jakarta, 16-17/5/2016. 
dapat menerapkan sanksi, yang biasanya merupakan sanksi sosial. ${ }^{41}$ Aturan-aturan dalam suatu wilayah sosial semi-otonom sangat mudah untuk dipengaruhi oleh aturan dari wilayah sosial semiotonom yang lain, utamanya negara; sehingga secara bersama-sama beroperasi dalam wilayah tersebut. Irianto mencontohkan, oleh karena masyarakat hukum adat Batak Toba juga terpengaruh oleh hukum waris yang diputuskan melalui putusan pengadilan negara, maka ketentuan hukum waris adat yang berlaku bagi masyarakat hukum adat Batak Toba berlaku bersama dengan yurisprudensi Mahkamah Agung dan menjadi acuan bagi penyelesaian sengketasengketa waris yang muncul kemudian di masyarakat tersebut. ${ }^{42}$

Selain masyarakat hukum adat Batak Toba, suku Lioyang di Kabupaten Ende juga merupakan suatu wilayah sosial semi-otonom yang mempunyai aturan tersendiri tentang penanganan ibu hamil secara tradisional melalui dukun. Sebagai suatu wilayah sosial semiotonom, kebijakan Pemerintah Daerah Kabupaten Ende tentang pelayanan kesehatan ibu dan bayi juga berpengaruh terhadap layanan penanganan ibu hamil yang diberikan oleh dukun. Berdasarkan fakta tersebut, Rimawati mengatakan bahwa di Suku Lio pelayanan persalinan tradisional yang dilakukan oleh dukun berkompetisi dengan pelayanan persalinan modern yang diberikan oleh bidan; bahkan tak jarang kompetisi tersebut berbuntut pada sengketa pelayanan kesehatan. ${ }^{43}$

Masyarakat hukum adat Minangkabau juga merupakan contoh lain dari wilayah sosial semi-otonom. Di sana aturan penguasaan tanah berdasarkan hukum adat setempat, yaitu tanah adat, tanah kaum, tanah pusaka, milik pribadi, dan pegang gadai. Di sisi lain, peraturan perundang-undangan juga mengatur tentang tanah adat atau disebut sebagai tanah ulayat. Hermayulis mengemukakan bahwa pengertian tanah ulayat dalam peraturan perundang-undangan berbeda dengan

41 Irianto, Perempuan di antara Berbagai Pilihan Hukum, hlm. 67.

42 Irianto, Perempuan di antara Berbagai Pilihan Hukum, hlm. 67.

43 Rimawati, "Pilihan Hukum Penyelesaian Sengketa Pelayanan Kesehatan Melalui Pranata Adat dan Pranata Hukum Formil” (Ringkasan Disertasi, Universitas Gadjah Mada, Yogyakarta, 2019), hlm. 166-67. 
tanah ulayat yang dikenal oleh masyarakat hukum adat Minangkabau; sehingga penerapan hukum pertanahan negara menimbulkan berbagai reaksi dari masyarakat hukum adat Minangkabau, seperti penolakan, penerimaan, adaptasi, dan asimilasi. ${ }^{44}$

Griffiths berpendapat, wilayah sosial semi-otonom merupakan suatu teori deskriptif tentang pluralisme hukum, yaitu teori heterogenitas normatif yang mencakup fakta bahwa ruang sosial itu lebih bersifat penuh daripada kosong dan kompleksitas norma berlaku dalam heterogenitas. ${ }^{45}$ Wilayah sosial semi-otonom dapat dikatakan sebagai suatu lapangan beroperasinya pluralisme hukum kuat di mana hukum dalam suatu masyarakat tidak berlaku secara seragam dan sistematis karena masyarakat tidak hanya tunduk pada hukum negara atau aturan yang dibuat oleh lembaga-lembaga negara.

Pendekatan pluralismehukum mengubah cara pandang terhadap masyarakat hukum adat. Para ahli hukum adat klasik menganggap bahwa masyarakat hukum adat merupakan masyarakat hukum yang otonom dengan otoritas penegak hukumnya dan juga harta kekayaan yang mereka miliki. Dalam perkembangannya, masyarakat hukum adat ini tumbuh dan berkembang dalam lingkup masyarakat hukum nasional dan internasional. Sebagai akibatnya, fungsionaris adat melahirkan hukum adat melalui proses interaksi dengan anggota masyarakat hukum lain. Itulah mengapa masyarakat hukum adat tidak lagi dapat dipandang sebagai masyarakat hukum yang otonom karena proses pembuatan hukumnya merupakan proses yang interaktif dan saling memengaruhi dengan masyarakat hukum lain.

\section{Penerapan Pendekatan Pluralisme Hukum dalam Studi Hukum Adat}

Pluralisme hukum merupakan suatu konsep yang menjelaskan bahwa

44 Hermayulis, "Penerapan Hukum Pertanahan dan Pengaruhnya terhadap Hubungan Kekerabatan pada Sistem Kekerabatan Matrilineal Minangkabau di Sumatera Barat” (Disertasi, Universitas Indonesia, Jakarta, 1999), hlm. 404-6.

45 Griffiths, "Memahami Pluralisme Hukum”, hlm. 113. 
ada berbagai macam hukum yang berlaku dan saling berinteraksi dalam suatu wilayah sosial. Pendekatan pluralisme hukum membantu peneliti untuk lebih sensitif ketika mengobservasi lapangan sosial yang menjadi objek penelitiannya karena dalam lapangan tersebut ada keberagaman hukum yang sedang berlangsung. Dalam kajian hukum adat, ada beberapa tulisan yang secara eksplisit menyebut menggunakan pendekatan pluralisme hukum. Ada juga kajian-kajian lain yang meskipun tidak secara eksplisit menyebut menggunakan pendekatan pluralisme hukum dalam analisisnya menunjukkan adanya fenomena pluralisme hukum.

Pembahasan terhadap penerapan pendekatan pluralisme hukum dalam studi hukum adat dikelompokkan dalam tiga kategori. Pertama, pluralisme hukum lemah, di mana negara mengakui hukum adat baik melalui peraturan perundang-undangan maupun putusan pengadilan. Kedua, pluralisme hukum kuat, yang dideskripsikan melalui konsep wilayah sosial semi-otonom yang menjelaskan interaksi antar hukum tanpa adanya dominasi dan melalui proses penyelesaian sengketa ketika para pihak melakukan forum shopping atau ketika forum penyelesaian sengketa melakukan shopping forum. Terakhir, pluralisme hukum yang digunakan untuk menjelaskan hubungan berbagai fenomena hukum antara hukum adat (lokal), nasional, dan internasional serta peran teknologi informasi dan komunikasi dalam menjembatani hubungan tersebut.

Pengakuan hukum negara terhadap hukum adat melalui peraturan perundang-undangan dapat ditemukan antara lain dalam bidang pertanahan dan pidana. Pluralisme hukum pertanahan dapat ditemukan dalam tulisan Sumardjono, Hermayulis, dan Warman; sedangkan dalam bidang pidana dapat ditemukan dalam tulisan Pusat Kajian Hukum Adat 'Djojodigoeno' Fakultas Hukum Universitas Gadjah Mada dan Koalisi Masyarakat Sipil Tolak Living Law dalam RKUHP. Sumardjono menjelaskan bagaimana hukum adat diadaptasi dan diintegrasikan ke dalam Undang-Undang Nomor 5 Tahun 1960 tentang Peraturan Dasar Pokok-Pokok Agaria (UUPA) dan urgensi harmonisasi dan unifikasi peraturan perundang-undangan di bidang sumber daya alam. Hermayulis menjelaskan perbedaan persepsi 
antara konsep hukum tanah adat yang dikenal dalam hukum adat Minangkabau dan yang diakui dalam peraturan perundangundangan; sehingga perlu sinkronisasi. Warman menjelaskan dinamika pengakuan negara terhadap struktur masyarakat hukum adat Minangkabau, Nagari, dan hak ulayat melalui peraturan daerah.

Menurut Sumardjono, adaptasi hukum adat dalam UUPA adalah dengan mengakui prinsip-prinsip dan konsep-konsep hukum adat yang berlaku secara umum dan mengintegrasikannya ke dalam hukum pertanahan nasional. ${ }^{46}$ Asas-asas dan konsep-konsep hukum tanah adat yang diakui dalam UUPA antara lain adalah asas pemisahan horizontal; asas terang, tunai, dan riil dalam transaksi tanah; konsep perolehan dan penghilangan hak atas tanah; konsep hubungan antara masyarakat hukum adat dan tanahnya yang bersifat publik-privat; serta pengakuan negara terhadap masyarakat hukum adat yang bersifat deklaratif. Tantangan pengelolaan pluralisme hukum yang berlaku di masyarakat tidak hanya tentang bagaimana mengadaptasi dan mengintegrasikan hukumnya dalam hukum negara, tapi kenyataan bahwa hukum negara itu sendiri adalah plural dan saling tumpang tindih satu sama lain.

Sumardjono berpendapat, disharmonisasi peraturan perundangundangan tentang sumber daya alam disebabkan oleh absennya prinsip-prinsip pembaruan agraria dan pembaruan sumber daya alam yang menjadi rujukan bersama dalam pengaturan sumber daya alam. ${ }^{47}$ Prinsip-prinsip tersebut adalah keutuhan Negara Kesatuan Republik Indonesia, keberlanjutan, keadilan sosial, demokrasi, dan kepastian hukum. Selain itu, prinsip-prisip yang dikemukakan Mahkamah Konstitusi dalam pengelolaan sumber daya alam juga perlu diimplementasikan dalam peraturan perundang-undangan. Berdasarkan hal tersebut, Sumardjono merasa bahwa hukum negara yang mengatur tentang sumber daya alam perlu untuk diharmonisasikan satu sama lain untuk mencapai unifikasi hukum.

Urgensi harmonisasi/sinkronisasi terhadap peraturan

46 Sumardjono, "Pluralisme Hukum Sumber Daya Alam”, hlm. 11-25.

47 Sumardjono, "Pluralisme Hukum Sumber Daya Alam”, hlm. 35-6. 
perundang-undangan yang mengatur tentang tanah adat juga disampaikan oleh Hermayulis. Meskipun UUPA mengatakan bahwa hukum adat merupakan dasar dari hukum pertanahan negara, konsep penguasaan adat atas tanah tidak secara tepat dapat diakui atau dikonversi dalam hak-hak atas tanah yang diakui oleh hukum negara. Sebagai contoh Keputusan Kepala Direktorat Agraria Sumatera Barat Nomor DA. 8920/III/2C/1983 yang memberikan kedudukan tanah Ganggam Bauntuak identik dengan tanah garapan.

Hermayulis berpendapat, menempatkan tanah Ganggam Bauntuak sebagai tanah garapan dengan hak pakai merupakan konversi yang tidak sesuai konsep penguasaan tanah Ganggam Bauntuak dalam hukum Adat Minangkabau. Dalam hukum adat Minangkabau, Ganggam Bauntuak merupakan hak suatu keluarga atas bagian dari milik bersama; sehingga tidak tepat dikonversi sebagai hak pakai. Menurut Hermayulis, sinkronisasi hak atas tanah berdasarkan hukum adat dan hukum negara perlu dilakukan berdasarkan penelusuran dengan pendekatan emik dan pengkajian secara etik; sehingga interpretasi negara terhadap hak atas tanah berdasarkan hukum adat tidak terlepas dari pola budaya dan nilai yang dianut oleh masyarakat tersebut. ${ }^{48}$

Warman menerapkan pendekatan pluralisme hukum untuk menjelaskan interaksi hukum adat dan hukum negara dalam aspek publik, pelaksanaan pemerintahan Nagari yang berkaitan dengan pengaturan sumberdaya agraria. ${ }^{49}$ Penelitian Warman menunjukkan bahwa interaksi antara hukum adat dan hukum negara melalui pegakuan terhadap stuktur kelembagaan adat Nagari dan penguasaan ulayat Nagari melalui peraturan daerah berubah dari waktu ke waktu. Peraturan negara tentang pemerintahan Nagari dapat ditelusuri sejak 1946 ketika Residen Sumatera Barat mengeluarkan Maklumat Residen Sumatera Barat Nomor 20 Tahun 1946 yang mengatur

48 Hermayulis, “Penerapan Hukum Pertanahan”, hlm. 216-7.

49 Kurnia Warman, "Pengaturan Sumberdaya Agraria pada Era Desentralisasi Pemerintahan di Sumatera Barat (Interaksi Hukum Adat dan Hukum Negara dalam Perspektif Keanekaragaman dalam Kesatuan Hukum) (Disertasi, Universitas Gadjah Mada, Yogyakarta, 2009), hlm. 288. 
tentang Walinegeri, Dewan Perwakilan Negeri, dan Dewan Harian Negeri.

Pada 1950-1963, pengakuan negara terhadap struktur adat Nagari berubah menjadi pengakuan terhadap Kepala Wilayah dan Dewan Perwakilan Rakyat Wilayah berdasarkan Peraturan Daerah Sumatera Tengah Nomor 50/GP/1950. Perubahan kembali terjadi dengan dikeluarkannya Surat Keputusan Gubernur Sumatera Barat Nomor 2/ Desa/ Gsb / Prt-1963 yang mengakui struktur pemerintahan Nagari yang terdiri dari Kepala Nagari, Badan Musyawarah Nagari, dan Musyawarah Gabungan. Aturan tentang struktur pemerintahan Nagari terus berubah hingga yang berlaku saat ini, yaitu Peraturan Daerah Sumatera Barat Nomor 7 Tahun 2018 tentang Nagari yang mengatur bahwa kelembagaan Nagari terdiri dari Kerapatan Adat Nagari, Pemerintahan Nagari, dan Peradilan Adat Nagari.

Pengakuan negara terhadap Ulayat Nagari atau sumberdaya agraria Nagari dimulai sejak Surat Keputusan Gubernur Sumatera Barat Nomor 2/Desa/Gsb/Prt-1963 yang mengakui Ulayat Nagari berupa bunga kayu, bunga pasir, bunga batu/karang. Pengakuan ini berubah dengan dikeluarkannya Surat Keputusan Gubernur Sumatera Barat Nomor 015/SGSB/1968 yang mengatur bahwa keuangan Nagari terdiri dari retribusi hasil hutan, karet rakyat, dan hasil bumi lain, serta hasil laut, danau, sungai, dan lain sebagainya. Surat Keputusan Gubernur Nomor 155/GSB-1974 kemudian mengatur harta benda Nagari terdiri dari pasar, tanah lapang atau tempat rekreasi, masjid atau surau, tanah, sungai, tebat dan laut Ulayat Nagari, bangunan, dan lain-lain.

Peraturan Daerah Sumatera Barat Nomor 7 Tahun 1981 dan Nomor 13 Tahun 1983 mengakui lembaga adat Kerapatan Adat Nagari yang tugasnya antara lain untuk menginventarisasi, menjaga, mengurus dan memanfaatkan kekayaan Nagari untuk kesejahteraan masyarakat Nagari serta menyerahkan kekayaan Nagari dari bekas Walinagari kepada Ketua Kerapatan Adat Nagari. Saat ini, negara mengakuikelembagaan nagari dan tanah ulayat serta pemanfaatannya melalui dua peraturan daerah terpisah. Peraturan Daerah Provinsi Sumatera Barat Nomor 6 Tahun 2008 mengakui tanah ulayat dan 
pemanfaatannya; sedangkan Peraturan Daerah Provinsi Sumatera Barat Nomor 7 Tahun 2018 mengakui kelembagaan pemerintahan Nagari.

Dalambidangpidana, pengakuan hukumnegara terhadaphukum adat dapat dilihat dalam RUU KUHP. Hukum adat dalam RUU KUHP diakui dengan istilah nilai hukum dan keadilan yang hidup, hukum yang hidup dalam masyarakat, kewajiban adat, norma kesusilaan, dan kewajiban adat setempat. Istilah-istilah tersebut digunakan dalam RUU KUHP sebagai pertimbangan dalam pemidanaan, dasar pemidanaan, dan jenis-jenis perkara pidana. Pusat Kajian Hukum Adat 'Djojodigoeno' Universitas Gadjah Mada dan Koalisi Masyarakat Sipil Tolak Living Law dalam RKUHP berpendapat bahwa pengakuan hukum adat dalam RUU KUHP merupakan rekonstruksi parsial atas hukum adat karena hukum adat hanya digunakan sebagai dasar atau pertimbangan pemidanaan. ${ }^{50}$ Padahal dalam ajaran melawan hukum yang bersifat negatif dikenal bahwa meskipun perbuatan seseorang melanggar peraturan perundang-undangan, apabila perbuatan tersebut tidak melawan hukum yang hidup dalam masyarakat, maka perbuatan tersebut tidak mengandung sifat melawan hukum. Utama mengatakan bahwa inkorporasi hukum adat dalam RUU KUHP merupakan contoh pluralisme hukum yang lemah karena semakin menguatkan dominasi hukum negara terhadap tatanan informal yang terinternalisasi dalam relasi dan perilaku warganya. ${ }^{51}$

Pluralismehukumlemahjuga dapat ditemukandalampengakuan hukum adat oleh pengadilan negara. Pasca dihapuskannya eksistensi peradilan adat dalam peraturan perundang-undangan Republik Indonesia, kewenangan peradilan adat dialihkan ke peradilan negara. Sebagai akibatnya, hakim peradilan negara berkewajiban untuk menggali, mengikuti, dan memahami nilai-nilai hukum yang hidup dalam masyarakat. ${ }^{52}$ Utama dan Aristya menemukan bahwa hakim

50 UGM \& Koalisi Masyarakat Sipil, Brief Paper, hlm. 21.

51 Tody Sasmitha Jiwa Utama, "Hukum yang Hidup dalam Rancangan Kitab Undang-Undang Hukum Pidana (KUHP): antara Akomodasi dan Negasi”, Masalah-Masalah Hukum, 49, 1 (2020), hlm. 23.

52 Lihat Penjalasan Umum Angka 7 Undang-Undang Nomor 14 Tahun 1970 tentang Ketentuan-Ketentuan Pokok Kekuasaan Kehakiman (Republik 
dalam pengadilan perdata mengakomodasi asas-asas dan norma hukum adat dalam penyelesaian perkara di pengadilan, seperti asas terang dalam perkara pergantian jenis kelamin. ${ }^{53}$ Sulastriyono dan Aristya menemukan bahwa hakim pengadilan negara menerapkan asas-asas hukum adat antara lain asas terang, tolong-menolong, keluargaan, dan kepantasan. ${ }^{54}$ Pradhani mengemukakan, hukum adat ditemukan oleh hakim dalam yurisprudensi Mahkamah Agung, doktrin, dan konsep tentang hukum adat. ${ }^{55}$ Pradhani juga mengatakan, selain asas-asas hukum, penemuan hukum oleh hakim dalam sengketa hukum adat juga merujuk pada hukum formal yang mengakui tentang hak-hak masyarakat hukum adat. ${ }^{56}$

Djojodigoeno berpendapat, pada prinsipnya pelaksanaan hukum dalam sistem hukum negara maupun sistem hukum adat sama-sama dengan cara menerapkan asas-asas yang bersifat umum ke dalam peristiwa-peristiwa konkret. ${ }^{57}$ Tidak hanya dalam putusan pengadilan, pengakuan negara terhadap hukum adat, sebagaimana disampaikan oleh Sumardjono, juga dengan mengabstraksi normanorma hukum adat yang bersifat konkret ke dalam asas-asas hukum adat yang bersifat umum dan kemudian diadaptasikan dan diintegrasikan ke dalam peraturan perundang-undangan. Menurut Simarmata, pengakuan negara terhadap hukum adat dengan cara mengabstraksi hukum adat dalam asas-asas dan konsep-konsep hukum yang bersifat umum untuk kemudian dapat diterapkan dalam kasus-kasus konkret merupakan pendekatan positivitik terhadap

Indonesia, 1970).

53 Utama dan Aristya, "Kajian tentang Relevansi Peradilan Adat", hlm. 65.

54 Sulastriyono dan Sandra Dini Febri Aristya, "Penerapan Norma dan AsasAsas Hukum Adat dalam Praktik Peradilan Perdata”, Mimbar Hukum, 24, 1 (2012), hlm. 28-30.

55 Pradhani, "Perspektif Pemikiran Hukum Barat”, hlm. 13.

56 Sartika Intaning Pradhani, "Traditional Rights of Indigenous People in Indonesia: Legal Recognition and Court Interpretation”, Jambe Law Journal, 1, 2 (2018), hlm. 192.

57 Sulastriyono dan Sartika Intaning Pradhani, "Pemikiran Hukum Adat Djojodigoeno dan Relevansinya Kini”, Mimbar Hukum, 30, 3 (2018), hlm. 456. 
hukum adat. ${ }^{58}$ Pluralisme hukum lemah/sentralisme hukum yang dilakukan dengan cara pendekatan hukum adat positivistik adalah untuk kepentingan penyelenggara negara supaya dapat mengelola keberagaman hukum adat dalam penyelenggaraan pemerintahan negara secara efektif.

Pluralisme hukum kuat di mana hukum saling berinteraksi dan tidak saling mendominasi dapat ditemukan dalam konsep wilayah sosial semi-otonom yang diperkenalkan oleh Moore. Konsep wilayah sosial semi otonom ini digunakan oleh Irianto untuk menjelaskan lokasi sosial penelitian disertasinya. Irianto menjelaskan, masyarakat hukum adat Batak Toba merupakan wilayah sosial semi-otonom. ${ }^{59}$ Di dalam masyarakat hukum adat Batak Toba terdapat banyak wilayah sosial semi-otonom lain yang lebih kecil, sehingga seorang individu Batak Toba merupakan anggota dari berbagai wilayah sosial semi otonom baik yang luas (negara) maupun yang sempit (misalnya komunitas marga/profesi) dalam waktu yang bersamaan. Masingmasing wilayah sosial semi-otonom tersebut mempunyai kapasitas untuk menciptakan aturan dan menerapkan sanksinya sendiri, salah satunya berkaitan dengan pewarisan, cara pembagiannya, dan pengelolaan perselisihan yang terjadi.

Menurut Irianto, aturan yang berlaku dalam suatu wilayah sosial semi-otonom sangat rentan terhadap pengaruh dari hukum wilayah sosial semi-otonom lain, seperti negara. ${ }^{60}$ Irianto menjelaskan bagaimana pengaruh dari hukum negara terhadap masyarakat hukum adat Batak Toba melalui forum shopping yang dilakukan pihak perempuan dan laki-laki dalam proses penyelesaian sengketa waris. ${ }^{61}$ Irianto juga menjelaskan bagaimana pengadilan adat dan pengadilan negara melakukan shopping forum untuk menentukan hukum mana yang berlaku dalam proses penyelesaian sengketa waris. ${ }^{62}$

Irianto juga mengatakan, pilihan hukum perempuan sebagai

58 Simarmata, "Pendekatan Positivistik dalam Studi Hukum Adat", hlm. 473.

59 Irianto, Perempuan di antara Berbagai Pilihan Hukum, hlm. 66-70.

60 Irianto, Perempuan di antara Berbagai Pilihan Hukum, hlm. 67.

61 Irianto, Perempuan di antara Berbagai Pilihan Hukum, hlm. 252-69.

62 Irianto, Perempuan di antara Berbagai Pilihan Hukum, hlm. 159-74. 
subjek lebih dari satu sistem hukum tidak bersifat dikotomis, tetapi kontinum karena perempuan memilih untuk sepenuhnya atau sebagian tunduk pada hukum negara maupun hukum adat atau secara tegas menolak hukum adat. ${ }^{63}$ Para pihak yang terlibat dalam proses penyelesaian sengketa waris, mengadopsi secara rasional institusi hukum tertentu untuk memenuhi kepentingannya sebagaimana ilustrasi berikut. Perempuan awalnya berhadapan dengan institusi hukum adat, namun ketika dirasa tidak mendatangkan rasa keadilan, maka sepenuhnya menundukkan diri pada institusi hukum negara. Di sisi lain, perempuan yang menundukkan diri sebagian pada hukum adat maka ia tidak berhak atas tanah pusaka; namun tanah objek sengketa adalah harta pencaharian, sehingga ia berhak atas harta waris. Ada kalanya perempuan memutuskan untuk menundukkan diri sepenuhnya terhadap hukum negara untuk melawan gugatan terhadap dirinya di pengadilan negara. Jika perempuan merasa tidak mampu untuk membawa sengketanya ke pengadilan negara, ia menundukkan diri pada hukum negara secara terbatas untuk melegalisasi surat keterangan sebagai ahli waris dan sertifikat harta perkawinan. Di saat yang lain, perempuan tidak membuat pilihan untuk menyelesaikan sengketa ketika lawan sengketa menawarkan pembagian harta waris yang dirasa tidak adil.

Di sisi lain, pihak lawan sengketa perempuan yang umumnya laki-laki tunduk sepenuhnya pada hukum negara ketika menghadapi gugatan perempuan atau menggugat perempuan. Di pengadilan negara, pihak laki-laki menolak tunduk pada hukum negara dan tunduk pada hukum adat ketika putusan pengadilan memberikan hak waris kepada perempuan. Sebaliknya, ketika putusan pengadilan tidak memberikan hak mewaris kepada perempuan, pihak laki-laki tunduk pada hukum negara.

Putusan pengadilan adat maupun negara pun beragam dalam menanggapi gugatan hak waris perempuan di masyarakat hukum adat Batak Toba. Ada hakim adat yang tidak memberikan waris (utamanya harta pusaka) kepada perempuan dan ada juga yang

63 Irianto, Perempuan di antara Berbagai Pilihan Hukum, hlm. 277-93. 
memberikan hak kelola (bukan hak milik) kepada perempuan. Sedangkan hakim pengadilan negara memberikan hak waris kepada perempuan dengan cara mengabaikan hukum adat, membuat rumusan baru, mengacu pada yurisprudensi yang memberikan hak waris kepada anak perempuan, atau mengacu pada substansi Undang-Undang Perkawinan yang memberikan hak waris kepada janda. Namun ada juga hakim negara yang menolak memberikan hak waris kepada perempuan dengan merujuk pada hukum adat yang tidak memberikan hak waris kepada perempuan ataupun yurisprudensi yang mengacu pada hukum adat tersebut. Selain itu, hakim pengadilan negara juga ada yang memberikan putusan bersifat win-win solution di mana perempuan dimenangkan sebagian dengan membuat rumusan putusan baru, mengacu pada yurisprudensi dan Undang-Undang Perkawinan yang memberikan hak mewaris kepada anak perempuan dan janda.

Selain di masyarakat hukum adat Batak Toba, saling pengaruh dan kompetisi antara pranata hukum negara dan pranata hukum adat juga dapat ditemukan dalam masyarakat hukum adat Minangkabau. Benda-Beckmann, Hermayulis, dan Warman mendeskripsikan bagaimana proses saling memengaruhi dan kompetisi antara hukum adat dan hukum negara. Benda-Beckmann menjelaskan tentang bagaimana para pihak dalam suatu sengketa membuat pilihan terhadap berbagai institusi penyelesaian sengketa yang ada di Minangkabau dan bagaimana institusi-institusi tersebut membuat keputusan terhadap sengketa-sengketa yang ditangani.

Benda-Beckmann mengilustrasikan kasus sengketa penguasaan kolam ikan antara Katik Basa dan Angku Duo. ${ }^{64}$ Katik Basa adalah seorang individu yang mengklaim hak atas kolam ikan, sedangkan Angku Duo merupakan wakil dari lingkungan masyarakat di sekitar kolam tersebut yang mengklaim hak atas kolam ikan. Ketika Katik Basa tidak sepakat dengan keputusan lingkungan masyarakat di sekitar kolam ikan, Angku Duo melaporkan Katik Basa kepada walikota dan polisi. Walikota dan polisi melakukan pilihan hukum

64 Benda-Beckmann, "Forum Shoppping and Shopping Forums”, hlm. 133. 
terhadap laporan yang disampaikan oleh Angku Duo. Walikota menanggapi laporan Angku Duo dengan mengirimkan Katik Basa kepada polisi dengan dasar bahwa Katik Basa merupakan pihak yang membuat masalah dalam lingkungan masyarakat. Polisi menahan Katik Basa selama beberapa hari. Ia juga berusaha untuk membatasi diri dari mencampuri urusan adat untuk menarik hati para fungsionaris adat dengan menyerahkan penyelesaian kasus Katik Basa kepada Dewan Adat. Setelah dikonfrontasi oleh Angku Duo dan lingkungan masyarakat, walikota serta polisi, Katik Basa mulai melakukan seleksiterhadap institusi penyelesaian sengketa. Katik Basa membawa sengketa ini ke Dewan Adat dengan alasan bahwa ia telah dikucilkan oleh warga masyarakat sebagai akibat dari sengketa penguasaan kolam ikan. Dalam hukum adat Minangkabau, kasus pengucilan adalah kasus yang serius.

Dalam kasus ini, Dewan Adat tidak langsung menerima kasus tersebut apalagi ada pertimbangan bahwa kasus tersebut diterima berdasarkan surat dari polisi. Dewan Adat berusaha untuk menggali isu hukum adat untuk dapat melegitimasi apakah Dewan Adat mempunyai yurisdiksi dalam kasus tersebut. Para anggota Dewan Adat sendiri tidak dalam satu kesepatakan apakah akan menerima kasus tersebut atau tidak. Salah satu anggota Dewan Adat yang merupakan teman baik walikota merasa bahwa sengketa tersebut bukan merupakan kewenangan Dewan, tetapi masuk dalam kewenangan lingkungan masyarakat sekitar kolam ikan. Meskipun telah melaporkan ke walikota dan polisi, Angku Duo dan lingkungan masyarakat sekitar kolam menolak jika kasus tersebut ditangani oleh Dewan Adat karena masuk dalam yurisdiksi lingkungan masyarakat. Setelah mendengar dari pendapat berbagai pihak, Dewan Adat memutuskan untuk mengembalikan kasus tersebut ke dalam yurisdiksi masyarakat sekitar kolam.

Berdasarkan kasus tersebut, untuk menentukan pilihan institusi hukum yang mana, pertama-tama pihak yang bersengketa akan membangun argumentasi tentang yurisdiksi. Ketika yurisdiksi sudah ditentukan, maka hukum prosedural mulai diberlakukan. Baik fungsionaris adat maupun para pihak akan memperdebatkan tentang 
prosedur dari proses penyelesaian sengketa. Benda-Beckmann mengatakan bahwa perdebatan tentang prosedur dalam proses penyelesaian sengketa melalui institusi adat merupakan konsekuensi dari struktur sosial-politik desa dan putusan merupakan kesepakatan dan diterima oleh seluruh pihak yang berperkara. ${ }^{65}$

Kompleksnya prosedur dalam proses penyelesaian sengketa melalui institusi adat membuat banyak konflik tidak menemukan jalan keluar di Dewan Adat. Meskipun tidak ada larangan untuk mengakses pengadilan negara, para pihak tidak selalu dapat langsung mengakses pengadilan negara jika tidak mendapatkan restu dari fungsionaris adat karena di pengadilan negara, fungsionaris adat juga kerap didatangkan sebagai saksi ahli. Berdasarkan hal tersebut, BendaBeckmann mengemukakan bahwa fungsionaris adat merupakan aktor penting dalam proses penyelesaian sengketa adat baik melalui institusi adat maupun melalui institusi negara. ${ }^{66}$

Selain Benda-Beckmann, studi Hermayulis juga menjelaskan bagaimana hukum pertanahan negara memengaruhi peran dari fungsionaris adat, mamak, dalam kehidupan masyarakat hukum adat Minangkabau. Hermayulis mengatakan, sertifikasi tanah menyebabkan peningkatan kepemilikan tanah secara pribadi dan berkurangnya penguasaan tanah bersama di bawah mamak. ${ }^{67}$ Dengan terbitnya sertifikat tanah, kujungan mamak ke rumah kemenakan untuk pengurusan tanah berkurang karena mamak merasa bahwa dengan diterbitkannya sertifikat sebagai alat bukti hak, berarti tidak perlu lagi menjaga dan melindungi tanah karena tanah sudah dilindungi oleh hukum. Selain itu, sertifikasi tanah juga secara tidak langsung membawa pengaruh terhadap hubungan kekerabatan matrilineal masyarakat hukum adat Minangkabau yang terikat berdasarkan tanah. Dengan adanya sertifikat tanah, jual beli tanah lebih mudah dilakukan, bahkan jual beli tanah tidak perlu izin dari mamak baik dengan sesama anggota masyarakat, maupun dengan non-anggota masyarakat adat.

65 Benda-Beckmann, "Forum Shoppping and Shopping Forums", hlm. 145.

66 Benda-Beckmann, "Forum Shoppping and Shopping Forums", hlm. 146.

67 Hermayulis, "Penerapan Hukum Pertanahan”, hlm. 358. 
Selain menjelaskan berkurangnya peran mamak sebagai akibat dari sertifikasi tanah, Hermayulis juga menjelaskan pilihan hukum warga masyarakat hukum adat Minangkabau pada proses penyelesaian sengketa gadai. Dalam hukum adat Minangkabau, gadai harus ditebus. Sedangkan berdasarkan Peraturan Pemerintah Pengganti Undang-Undang Nomor 56 Tahun 1960, gadai yang telah dikuasi selama tujuhtahun/lebih harus dikembalikan kepada pemilik tanah tanpa hak untuk menuntut kembali pembayaran uang tebusan. Dalam praktik gadai di masyarakat hukum adat Minangkabau, uang gadai dapat lebih dari harga jual lepas dari tanah objek gadai. Dengan demikian, ketentuan dalam undang-undang tersebut dapat merugikan pemegang gadai; di sisilain, ketentuan ini dapat membawa keuntungan untuk penjual gadai.

Hermayulis menemukan bahwa ketentuan hukum negara yang menghapuskan hak membayar uang gadai setelah tujuh tahun digunakan sebagai dasar penjual gadai menggugat pemegang gadai untuk mengembalikan tanahnya tanpa pembayaran penebusan gadai. $^{68}$ Putusan Pengadilan Negeri Solok Nomor 10/Pdt/G/ 1986 memerintahkan untuk mengembalikan tanah gadai objek sengketa tanpa uang penebusan gadai. Berdasarkan fakta tersebut, dengan diterbitkannya hukum negara tentang hapusnya hak untuk membayar uang penebusan gadai, terjadi perubahan terhadap sikap dan perilaku anggota masyarakat hukum adat Minangkabau dalam praktik jual gadai. Anggota masyarakat pun memilih pengadilan negara dan hukum negara untuk menyelesaikan sengketa adat tentang gadai. Di sisi lain, institusi negara juga mengakui adanya praktik gadai secara adat, namun memutus sengketa tersebut berdasarkan hukum negara.

Interaksi antara institusi adat Minangkabau dan institusi negara juga dijelaskan oleh studi Warman. Menurutnya, pemerintah daerah, pengadilan negeri, dan kerapatan adat Nagari saling memengaruhi dalam proses penyelesaian sengketa. ${ }^{69}$ Meskipun peradilan adat tidak lagi diakui dalam peraturan perundang-undangan nasional,

68 Hermayulis, "Penerapan Hukum Pertanahan”, hlm. 390.

69 Warman, "Pengaturan Sumberdaya Agraria”, hlm. 298-313. 
Peraturan Daerah Sumatera Barat Nomor 13 Tahun 1983 mengakui fungsi peradilan adat yang dijalankan oleh Kerapatan (Adat) Nagari untuk menyelesaikan sengketa sako (gelar) dan pusako (pusaka).

Di Sumatera Barat, pengakuan negara terhadap pengadilan adat tidak menghambat warga untuk mengakses keadilan melalui pengadilan negara, utamanya dalam sengketa tanah adat. Menanggapi hal tersebut, Pengadilan Tinggi Padang mengeluarkan Surat Edaran Nomor W3.DA.HT.04.02-3633 tanggal 27 Mei 1985 tentang Memperlakukan Hukum Adat Minangkabau Mengenai Sengketa Tanah Pusaka Tinggi. Berdasarkan surat edaran tersebut, ketika Pengadilan Negeri menangani perkara sengketa tanah adat, hakim perlu menanyakan apakah sengketa tanah adat tersebut telah diselesaikan dalam tingkat Kerapatan Adat Nagari. Jika belum, maka hakim perlu menolak perkara tersebut; dan jika sudah, maka putusan Kerapatan Adat Nagari perlu dilampirkan dalam gugatan sebagai pedoman bagi hakim untuk menyelesaikan sengketa tersebut. Menanggapi Surat Edaran tersebut, Lembaga Kerapatan Adat Alam Minangkabau mengeluarkan Surat Edaran Nomor 07/LKAAM-SBVI-1985 tanggal 10 Juni 1985 tentang Penyelesaian Persengketaan Perdata Adat.

Pemerintah Daerah Sumatera Barat tidak hanya mengakui eksistensi Kerapatan Adat Nagari, tetapi juga mengatur pedoman pelaksanaan tugas Kerapatan Adat Nagari dengan mengeluarkan Keputusan Gubernur Nomor 8 Tahun 1994 tentang Pedoman Acara Penyelesaian Sengketa Adat di Lingkungan Kerapatan Adat Nagari dalam Provinsi Daerah Tingkat I Sumatera Barat. Dalam Keputusan tersebut dilampirkan juga contoh-contoh format surat panggilan, gugatan, jawaban gugatan, berita acara sidang dan putusan. Sebagaimana disampaikan oleh Benda-Beckmann, penyelesaian sengketa adat di Minangkabau berjenjang. Institusi Kerapatan Adat Nagari merupakan institusi adat tertinggi, sehingga tidak semua sengketa adat akan diselesaikan melalui Kerapatan Adat Nagari. Berdasarkan temuan Warman, tidak hanya putusan pengadilan negara yang mengakui hukum adat, putusan Kerapatan Adat Nagari juga ikut mengikuti format yang telah dibuat oleh pemerintah daerah 
dan ada juga putusan Kerapatan Adat Nagari yang mempersilakan pihak yang merasa tidak puas untuk melanjutkan ke pihak yang berwenang. ${ }^{70}$

Selain masyarakat hukum adat Batak Toba dan Minangkabau, suku Lio di Kabupaten Ende juga merupakan wilayah sosial semiotonom yang terpengaruh dengan kebijakan negara tentang pelayanan kesehatan untuk ibu hamil, khususnya persalinan melalui tenaga kesehatan (bidan) dan larangan untuk melakukan persalinan secara tradisional melalui dukun bayi. Dalam disertasinya, Rimawati mendeskripsikan proses penyelesaian sengketa kematian ibu dan/ atau bayi dalam proses persalinan di suku Lio. ${ }^{71}$

Meskipun telah ada larangan dari negara untuk tidak mengakses layanan pengobatan tradisional, ibu hamil di suku Lio tetap mengakses layanan dukun bayi sebagai persiapan untuk persalinan. Bahkan dalam proses persalinan pun, tidak jarang ibu hamil mengakses layanan dukun bayi tanpa pendampingan dari bidan karena bidan tidak selalu stand by; sehingga akses terhadap dukun bayi dalam proses persalinan menjadi lebih mudah. Persalinan melalui bidan juga tidak dapat diakses langsung dari rumah karena hukum negara melarang bidan untuk melakukan layanan persalinan di rumah warga dan harus di puskesmas/puskesmas pembantu. Hal itu juga dirasa menyulitkan bagi warga; sehingga dukun bayi tetap menjadi pilihan untuk membantu persalinan ibu hamil di Suku Lio.

Sengketa layanan kesehatan muncul ketika layanan kesehatan dan persalinan baik yang diberikan oleh dukun bayi mupun bidan berakibat pada kematian ibu danbayi. Dalam kasus tersebut, pihak keluarga melaporkan dukun bayi dan bidan ke kepala desa atau ke fungsionaris adat mosalaku pu'u untuk diselesaikan dalam sidang adat teke tara.Jika laporan disampaikan kepada kepala desa, maka kepala desa menyerahkan urusan penyelesaian sengketa melalui Mosalaku $P u^{\prime} u$. Proses penyelesaian sengketa melalui Mosalaku $P u^{\prime} u$ dalam sidang adat teke tera adalah dengan cara memanggil seluruh pihak yang terlibat dalam sengketa untuk memberikan keterangan. Berdasarkan

70 Warman, "Pengaturan Sumberdaya Agraria”, hlm. 303-9.

71 Rimawati, "Pilihan Hukum Penyelesaian Sengketa”, hlm. 131-42. 
keterangan tersebut, akan diputuskan siapa pihak yang bersalah dan harus membayar ganti kerugian kepada pihak yang melapor serta untuk mendanai biaya upacara adat untuk mengembalikan keseimbangan kosmis masyarakat yang terganggu. Dalam sengketa kematian bayi, dukun bayi sering diputus bersalah dan diperintahkan untuk membayar ganti kerugian kepada pelapor. Ada kalanya bidan juga diputus bersalah dan diperintahkan bersama dengan dukun bayi untuk mendanai penyelenggaraan ritual adat untuk mengembalikan keseimbangan kosmis yang terganggu.

Bagi pihak pelapor, institusi adat tetap menjadi pilihan utama daripada penyelesaian sengketa melalui pengadilan negara karena pertimbangan jarak dan biaya. Fungsionaris adat dalam menghadapi kasus sengketa layanan kesehatan yang melibatkan bidan dan dukun bayi juga menerima penjelasan dari bidan tentang bagaimana bekerjanya hukum negara. Bidan ketika dilaporkan untuk bertanggung jawab atas kematian bayi karena menolak memberikan pelayanan kesehatan di rumah menggunakan argumentasi bahwa ada larangan dan ancaman pidana berdasarkan hukum negara jika bidan memberikan layanan persalinan di rumah warga. Hakim pengadilan adat juga menerima penjelasan dari bidan tersebut dan cenderung untuk tidak meminta pertanggungjawaban dari bidan dan memutuskan bahwa bidan tidak bersalah dalam kasus tersebut.

Fenomena pluralisme hukum forum shopping yang dilakukan oleh institusi pengadilan negara dideskripsikan oleh Fitzpatrick dalam proses penyelesaian sengketa pembebasan tanah untuk kepentingan umum. Fitzpatrick berpendapat bahwa pengadilan melakukan legal norm shopping untuk kepentingan negara dan menerapkan norma hukum atau prinsip hukum yang umum dalam suatu kasus konkret tanpa menyediakan pertimbangan hukum yang dapat diprediksi atau konsisten. ${ }^{72}$ Sebagai contoh Mahkamah Agung menerapkan prinsip fungsi sosial dari tanah dalam sengketa Dam Kedung Ombo. Dalam kasus ini, prinsip fungsi sosial dari tanah yang diadaptasi dari hukum adat dalam UUPA diterapkan oleh pengadilan untuk melegitimasi

72 Daniel Fitzpatrick, "Disputes and Pluralism in Modern Indonesian Land Law”, Yale Journal of International Law”, 22, 1 (1997), hlm. 204. 
kontrol negara atas tanah.

Putusan Peninjauan Kembali memutuskan bahwa semua hak atas tanah mempunyai fungsi sosial, sehingga hak individu atas tanah harus dikalahkan jika berhadapan dengan kepentingan umum. Oleh karena Dam Kedung Ombo adalah kepentingan umum dan hukum harus mendukung program pembagunan nasional sebagaimana diatur dalam peraturan perundang-undangan, maka pengadilan tidak perlu mempertimbangkan apakah persyaratan dan pertimbangan yang ditentukan oleh peraturan perundang-undangan telah diterima dan memuaskan bagi pihak pemegang hak atas tanah. Putusan Peninjauan Kembali ini membatalkan Putusan Kasasi Mahkamah Agung yang memerintahkan pemerintah untuk membayar ganti kerugian atas tanah, bangunan, hasil panen, dan juga kerugian yang diderita oleh masyarakat sebagai akibat dari proyek Dam Kedung Ombo.

Selain kasus Dam Kedung Ombo, Fizpatrick jugamenjelaskan peran pengadilan negara dan Ketua Mahkamah Agung dalam putusan pengadaan tanah untuk Bandara Sentani di Irian Jaya (saat ini Papua). Mahkamah Agung memerintahkan Gubernur Irian Jaya untuk membayar ganti kerugian atas kehilangan tanah adat untuk pembangunan bandara. Gubernur menolaknya, dengan alasan tidak mempunyai dana dan sebagai akibatnya eksekusi terhadap putusan tersebut mengalami kebuntuan. Berdasarkan kewenangannya, Ketua Mahkamah Agung Soerjono, mengeluarkan surat untuk memberikan intruksi dan pedoman bagi pengadilan yang lebih rendah, khususnya untuk mengarahkan Pengadilan Negeri Jayapura untuk tidak melakukan eksekusi terhadap putusan tersebut. Berdasarkan hal itu, Fitzpatrick berpendapat bahwa dalam praktiknya sistem peradilan negara Indonesia tidak hanya terdiri dari pengadilan negeri, banding, kasasi, peninjauan kembali; tetapi juga Surat Edaran Ketua Mahkamah Agung yang memberikan pedoman bagi pengadilan di bawahnya tentang bagaimana untuk mengeksekusi putusan Mahkamah Agung. ${ }^{73}$

73 Fitzpatrick, "Disputes and Pluralism”, hlm. 205. 
Terakhir, pembahasan penerapan pluralisme hukum dalam kajian hukum adat adalah kajian yang menjelaskan tentang hubungan fenomena hukum antara hukum adat (lokal), nasional, dan internasional serta peran teknologi informasi dan komunikasi dalam menjembatani hubungan tersebut. Hukum adat terkoneksi dengan hukum internasional ketika interaksi antaranggota masyarakat hukum adat yang semula berlangsung di tingkat lokal mengalami eskalasi dalam tingkat internasional. Misal, interaksi pasca referendum dan kemerdekaan negara Timor Leste dari Indonesia. Sebagai akibatnya, sebagaimana dijelaskan oleh Kase, konflik tanah adat yang semula menjadi masalah antaranggota masyarakat adat sebagai warga negara Indonesia menjadi konflik antaranggota masyarakat adat antarnegara, yaitu warga negara Indonesia dan warga negara Timor Leste. Penyelesaian konflik pun tidak dapat hanya melibatkan fungsionaris adat di masing-masing negara, tetapi perlu ada intervensi dari pemerintah negara karena konflik batas wilayah negara merupakan konflik internasional.

Kase menjelaskan bagaimana hukum adat dapat berperan dalam penyelesaian sengketa internasional tentang perbatasan negara antara Indonesia dan Timor Leste. ${ }^{74}$ Berdasarkan fakta sejarah, Pulau Timor ditinggali oleh lima suku Besar, yaitu Suku Helong, Dawan, Tetun, Kemak, dan Marae. Namun, ikatan kekerabatan masyarakat yangtinggal di Timor Barat, yang merupakan wilayah dari Indonesia, dan Timor Leste berasal dari lelulur yang sama; sehingga mempunyai nilai-nilai budaya yang sama. Setelah berdirinya negara Timor Leste, muncul sengketa perbatasan Indonesia dan Timor Leste. Sengketa batas wilayah bukanlah hal baru bagi masyarakat di perbatasan Indonesia-Timor Leste. Secara sosiologis masyarakat yang tinggal di perbatasan antara Indonesia dan Timor Leste masih tunduk dalam struktur hukum adat yang sama, yang juga mempunyai aturan tentang pertanahan, batas wilayah, penguasaan dan pengelolaan sumber daya alam. Berdasarkan hal tersebut, terbentuknya negara Timor Leste tidak serta merta memisahkan ikatan kekerabatan

74 Kase, Model Penyelesaian Sengketa Internasional, hlm. 120. 
atau menghapuskan berlakunya hukum adat pada masyarakat di perbatasan Indonesia dan Timor Leste. Namun, dengan terbentuknya negara Timor Leste, kasus sengketa tanah antarwarga masyarakat di perbatasan bukan hanya kasus antarorang-perseorangan di suatu masyarakat adat, tetapi menjadi sengketa internasional tentang tata batas wilayah negara yang melibatkan dua orang berbeda kewarganegaraan.

Berdasarkan realitas bahwa sengketa tanah antaranggota masyarakat adat tentang tanah di wilayah perbatasan merupakan sengketa internasional tentang batas wilayah antardua negara, para fungsionaris adat merasa kesulitan untuk menerapkan hasil kesepakatan antarpihak yang telah diselesaikan secara hukum adat. Berdasarkan hal tersebut, fungsionaris adat setempat meminta kepada Pemerintah Pusat Indonesia untuk berkoordinasi dengan Pemerintah Timor Leste supaya dalam memfasilitasi pertemuan antartokoh adat di wilayah perbatasan negara untuk dapat menyelesaikan sengketa kawasan perbatasan secara damai.

Fenomenahukuminternasionaldannasionalyangmempengaruhi kehidupan masyarakat hukum adat juga ditemukan dalam disertasi Campbell-Nelson. ${ }^{75}$ Iamengungkapkan, kebijakanPemerintahDaerah Kabupaten Timor Tengah Selatan sebagai implikasi dari UndangUndang Pemerintahan Daerah yang memberikan kewenangan bagi pemerintah daerah untuk memberikan izin pertambangan batu marmer telah memengaruhi kehidupan masyarakat hukum adat Mollo. Pertambangan batu marmer di wilayah masyarakat hukum adat Mollo menimbulkan resistensi dan gerakan perlawanan dari masyarakat.

Pada saat terjadi gerakan perlawanan terhadap praktek tambang di Timor Tengah Selatan, di Kawasan Timor Barat sedang terjadi referendum untuk kemerdekaan Timor Leste. Sebagai akibatnya, fokus aparat keamanan dan pertahanan negara, khususnya militer, adalah untuk mengamankan jalannya referendum di kawasan perbatasan. Campbell-Nelson menemukan bahwa konsentrasi mili-

75 Campbell-Nelson, “Learning Resistance in West Timor”, hlm. 128-9. 
ter di kawasan militer untuk mengamankan referendum membuat gerakan perlawanan terhadap pertambangan batu marmer tidak mendapatkan intervensi militer. Menurut Campbell-Nelson, tidak ada intervensi militer untuk mengamankan pertambangan berpengaruh terhadap keberhasilan masyarakat hukum adat Mollo untuk menghentikan praktik pertambangan di wilayah adatnya.

Kase dan Campbell-Nelson sama-sama menunjukkan bagaimana fenomena dalam level internasional berpengaruh terhadap perkembangan hukum adat. Kase menunjukkan eskalasi hukum adat yang bekerja dalam level internasional ketika sengketa antaranggota masyarakat hukum adat menjadi sengketa internasional antarwarga negara tentang batas wilayah negara. Campbell-Nelson menjelaskan fenomena internasional referendum di Timor Leste membuat aparat militer berkonsentrasi untuk bekerja di daerah perbatasan. Dengan demikian, mereka tidak merepresi konflik tambang yang terjadi di masyarakat hukum adat di Timor Tengah Selatan. Tidak hadirnya aparat militer dalam konflik tambang, membuat resistensi masyarakat dalam mempertahankan hukum adat pengaturan sumber daya alamnya berlangsung lebih efektif. Masyarakat sebagai warga sipil tidak perlu melawan aparat militer dan dapat fokus dalam gerakan resistensi menolak praktek tambang yang dilakukan oleh perusahaan tambang dan aparat pemerintah darah yang mengeluarkan izin tambang.

Arus informasi juga memengaruhi interaksi antara hukum adat dan hukum internasional. Sebagaimana disampaikan oleh BendaBeckmann bahwa observasi terhadap lapangan sosial dalam kajian hukum adat hari ini tidak terbatas pada wilayah geografis untuk mengamati perilaku masyarakat secara tatap muka, tetapi juga perlu diamati jalannya alur informasi melalui teknologi informasi dan komunikasi. ${ }^{76}$ Ginting, dkk. mengungkapkan bagaimana peran

76 Perkembangan hukum adat mengalami dinamikanya tersendiri seiring perkembangan dan penggunaan teknologi informasi dan komunikasi. Munculnya berbagai gerakan untuk merekognisi hak masyarakat hukum adat, yang bahkan meluas secara transnasional, salah satunya didorong oleh penggunaan teknologi informasi dan komunikasi yang intensif. Muhammad Dahlan, "Rekognisi Hak Masyarakat Hukum Adat dalam 
dari teknologi informasi dan komunikasi dalam membagun jaringan resistensi terhadap Merauke Integrated Food and Energy Estate. ${ }^{77}$ Menurut Ginting, dkk., teknologi informasi dan komunikasi berperan untuk menjembatani tantangan terbatasnya kapasitas untuk melakukan advokasi yang dihadapi oleh masyarakat hukum adat Malind yang secara langsung terdampak oleh Merauke Integrated Food and Energy Estate dan non-governmental organization baik di lokal Merauke maupun di Papua dan kebutuhan data empiris darinon-governmental organization di level nasional dan internasional mempunyai kemerdekaan dan akses yang luas untuk melakukan kampanye dan advokasi terhadap kasus penyerobotan tanah adat masyarakat hukum adat Malind untuk Merauke Integrated Food and Energy Estate. Meskipun jaringan nasional dan internasional mempunyai akses yang luas untuk melakukan advokasi, data empiris tentang situasi terkini yang terjadi terhadap masyarakat hukum adat Malind sebagai akibat dari Merauke Integrated Food and Energy Estate ada di level lokal. Jaringan nasional dan internasional perlu asupan dapat empiris dari jaringan lokal untuk dapat menyusun bahan-bahan kampanye dan advokasi. Di situlah peran dari teknologi informasi dan komunikasi untuk dapat memangkas jarak dan mengomunikasikan informasi yang terjadi di tingkat lokal ke level nasional dan internasional.

\section{E. Kesimpulan}

Pendekatan pluralisme hukum memahami hukum adat tidak sebagai suatu ketertiban hukum yang terpisah atau termarginalisasi dari ketertiban hukum yang lain, tetapi secara dinamis terus berinteraksi dengan hukum negara maupun hukum internasional. Interaksi hukum adat dengan hukum negara melahirkan antara lain hukum adat dalam format hukum negara, pengakuan hukum negara terhadap hukum adat melalui berbagai peraturan perundang-undangan, dan pengetahuan tentang apa yang dimaksud dengan hukum dari berbagai aktor dan institusi hukum negara. Pluralisme hukum juga

Konstitusi”, Undang: Jurnal Hukum, 1, 2 (2018), hlm. 189.

77 Ginting dan Espinosa, "Indigenous Resistance to Land Grabbing”, hlm. 5. 
menjelaskan fenomena hukum adat dalam ranah internasional baik melalui teknologi maupun kemerdekaan suatu negara. Teknologi memperluas cakupan penyebarluasan pengetahuan tentang hukum adat, sehingga pengetahuan hukum adat dapat sampai pada komunitas internasional. Hukum adat memasuki ranah hukum internasional ketika antarnegara membuat identitas anggota masyarakat hukum adat sebagai satu kesatuan hukum menjadiberbeda kewarganegaraan. Hal tersebut membuat sengketa adat memasuki ruang kompleksitas baru dalam sengketa hukum antarnegara.

Pendekatan pluralisme hukum membawa perubahan terhadap pandangan tentang apa itu masyarakat hukum adat. Masyarakat hukum adat tidak dapat lagi dipandang sebagai masyarakat hukum yang otonom karena dalam perkembangannya masyarakat hukum adat tumbuh dan berkembang dalam lingkup masyarakat hukum nasional dan internasional. Sebagai akibatnya, fungsionaris adat menciptakan hukum adat melalui proses interaksi dengan anggota masyarakat hukum lain. Itulah mengapa masyarakat hukum adat tidak lagi dapat dipandang sebagai masyarakat hukum yang otonom karena proses pembuatan hukumnya merupakan proses yang interaktif dan saling memengaruhi dengan masyarakat hukum lain.

Penerapan pendekatan pluralisme hukum dalam studi hukum adat dapat dikelompokkan dalam tiga kategori. Pertama, pluralisme hukum lemah, di mana negara mengakui hukum adat baik melalui peraturan perundang-undangan maupun putusan pengadilan. Kedua, pluralisme hukum kuat, yang dideskripsikan melalui konsep wilayah sosial semi-otonom yang menjelaskan interaksi antar hukum tanpa adanya dominasi dan melalui proses penyelesaian sengketa ketika para pihak melakukan forum shopping atau ketika forum penyelesaian sengketa melakukan shopping forum. Terakhir, pluralisme hukum multi-sited yang digunakan untuk menjelaskan hubungan berbagai fenomena hukum antara hukum adat (lokal), nasional, dan internasional serta peran teknologi informasi dan komunikasi dalam menjembatani hubungan tersebut. 


\section{Daftar Pustaka}

Abbas, Ilham, dkk. "Hak Penguasaan Istri terhadap Mahar Sompa Perkawinan Adat Bugis Makassar (Kajian Putusan PA Bulukumba Nomor 45 / Pdt.G / 2011 / PABlk)". Kanun Jurnal Ilmu Hukum, 20, 2 (2018): 203-18. DOI: 10.24815/kanun.v20i2.10659.

Asrinaldi dan Yoserizal. "Problems with the Implementation of Adat Basandi Syarak Syarak Basandi Kitabullah Philosophy”. Masyarakat, Kebudayaan dan Politik, 33, 2 (2020): 162-73. DOI: 10.20473/mkp.V33I22020.162-173.

Atmaja, Gede Marhaendra Wija. "Politik Pluralisme Hukum dalam

Pengakuan Kesatuan Masyarakat Hukum Adat dengan Peraturan Daerah”. Disertasi, Universitas Brawijaya, Malang, 2012.

Barnes, R. H. "A Catholic Mission and the Purification of Culture: Experience in An Indonesia Community". JASO, 23, 2 (1992): 169-80.

Bemmelen, Sita Thamar van dan Mies Grijns. "Relevansi Kajian Hukum Adat: Kasus Perkawinan Anak dari Masa ke Masa”. Mimbar Hukum, 30, 3 (2018): 516-43. DOI: 10.22146/jmh.38093. Benda-Beckmann, Franz von dan Keebet von Benda-Beckmann.

"Myths and Stereotypes about Adat Law: A Reassessment of Van Vollenhoven in the Light of Current Struggles over Adat Law in Indonesia". Bijdragen tot de Taal-, Land-en Bolkenkunde, 168, 2 / 3 (2011): 167-95. DOI: 10.2307/ 41288760.

Benda-Beckmann, Franz von, Keeben von Benda-Beckmann, dan Anne Griffiths. "Mobile People, Mobile Law: An Introduction". Dalam Mobile People, Mobile Law Expanding Legal Relations in a Contracting World, diedit oleh Franz von Benda-Beckmann,

Keeben von Benda-Beckmann dan Anne Griffiths, 1-25.

Burlington: Ashgate Publishing Company, 2005.

Benda-Beckmann, Keebet von. "Forum Shoppping and Shopping

Forums: Dispute Processing in A Minangkabau Village in West Sumatera”. Journal of Legal Pluralism, 19 (1981): 117-59. DOI: 10.1080/07329113.1981.10756260.

Campbell-Nelson, Karen. "Learning Resistance in West Timor". 
Disertasi, University Massachusetts Amherst, Armherst, 2003.

Dahlan, Muhammad. "Rekognisi Hak Masyarakat Hukum Adat dalam Konstitusi”. Undang: Jurnal Hukum, 1, 2 (2018): 187-218. DOI: 10.22437 / ujh.1.2.187-218.

Fitzpatrick, Daniel. "Disputes and Pluralism in Modern Indonesian Land Law”. Yale Journal of International Law, 22, 1 (1997): 171212.

Ginting, Wiranta Yudha dan Crsitina Espinosa. "Indigenous

Resistance to Land Grabbing in Mereauke, Indonesia: The Importance and Limits of Identity Politics and the Global-Local Coalitions". International Journal of Social Science and Business, 1, 3 (2016): 1-14.

Griffiths, John. "Memahami Pluralisme Hukum, Sebuah Deskripsi Konseptual". Dalam Pluralisme Hukum: Sebuah Pendekatan Interdisiplin, diedit oleh Perkumpulan untuk Pembaharuan Hukum Berbasis Masyarakat dan Ekologis (HuMa), 69-117. Jakarta: Perkumpulan untuk Pembaharuan Hukum Berbasis Masyarakat dan Ekologis (HuMa), 2005.

Griffiths, John. "What is Legal Pluralism?". Journal of Legal Pluralism and Unofficial Law, 24, 2, (1986): 1-55. DOI: 10.1080/07329113.1986.10756387.

Hermayulis. "Penerapan Hukum Pertanahan dan Pengaruhnya terhadap Hubungan Kekerabatan pada Sistem Kekerabatan Matrilineal Minangkabau di Sumatera Barat”. Disertasi, Universitas Indonesia, Jakarta, 1999.

Hurgronje, C. Snouck. The Achehnese Vol. I. Terjemahan A.W.S. O’Sullivan. Leyden: Late E.J. Brill, 1906.

Irianto, Sulistyowati. Perempuan di antara Berbagai Pilihan Hukum (Studi mengenai Strategi Perempuan Batak Toba untuk Mendapatkan Akses kepada Harta Waris melalui Proses Penyelesaian Sengketa). Jakarta: YayasanPustaka Obor Indonesia, 2012.

Irianto, Sulistyowati. "Pluralisme Hukum dalam Perspektif Global". Dalam Kajian Sosio-Legal, diedit oleh Adrian W. Bedner, dkk., 15770. Denpasar \& Jakarta: Pustaka Larasan, Universitas Indonesia, Universitas Leiden, Universitas Groningen, 2012. 
Jayus, Jaja Ahmad. "Eksistensi Pewarisan Hukum Adat Batak Kajian Putusan Nomor 1/PDT.G.2015/PB.Blg dan Nomor 439/ PDT/2015/PT-Mdn”. Jurnal Yudisial, 12, 2 (2019): 235-53. DOI: $10.29123 /$ jy.v12i2.384.

Kase, Dhesy A. Model Penyelesaian Sengketa Internasional Berbasis Hukum Adat. Kupang: Media Centre Publishing, 2018.

Masril dan Ade Kosasih. "Keberlakukan Asas Ne Bis in Idem terhadap Putusan Pengadilan Adat dalam Tata Hukum Indonesia”. AlImarah: Jurnal Pemerintahan dan Politik Islam, 4, 1, (2019): 49-56. DOI: $10.29300 /$ imr.v4i1.2167.

Moore, Sally Falk. "Law and Social Change: the Semi-Autonomous Social Field as an Appropriate Subject of Study". Law and Society Review, 7, 4 (1972): 719-46. DOI: 10.2307/ 3052967.

Pradhani, Sartika Intaning. "Perspektif Pemikiran Hukum Barat dalam Penemuan Hukum Adat oleh Hakim: Studi Kasus Putusan Sengketa Tanah Adat di Pengadilan Negeri Muara Teweh, Padang, Makale, dan Painan”. Bhumi: Jurnal Agraria dan Pertanahan, 6, 1 (2020): 1-14. DOI: 10.31292/jb.v6i1.420.

Pradhani, Sartika Intaning. "Traditional Rights of Indigenous People in Indonesia: Legal Recognition and Court Interpretation”. Jambe Law Journal, 1, 2 (2018): 177-205. DOI: 10.22437/jlj.1.2.177-205.

Rasyid, Laila M. "Penerapan Norma Adat Terang dan Tunai dalam Praktek Peradilan Perdata (Kajian Putusan Pengadilan Nomor 23/Pdt.G/2013/PN.Bj). Jurnal Ilmu Hukum Reusam, 7, 2 (2019): $1-14$.

Rasyid, Laila M. "Pengakuan terhadap Hukum Adat dalam Kajian Putusan Kasus Tanah Hibah Adat di Pengadilan Sigli”. Riau Law Journal, 1, 1 (2017): 61-72. DOI: 10.30652/rlj.v1i1.4177.

Redi, Ahmad, Yuwono Prianto, Tundjung Herning Sitabuana, dan Ade Adhari. "Konstitusionalitas Hak Ulayat Masyarakat Hukum Adat atas Hak Ulayat Rumpon di Provinsi Lampung”. Jurnal Konstitusi, 14, 3 (2017): 463-88. DOI: 10.31078/jk1431.

Rimawati. "Pilihan Hukum Penyelesaian Sengketa Pelayanan Kesehatan Melalui Pranata Adat dan Pranata Hukum Formil”. Ringkasan Disertasi, Universitas Gadjah Mada, Yogyakarta, 
2019.

Roewiastoeti, Maria Rita. "Dampak Sosial Politik Putusan Mahkamah

Konstitusi Nomor 35/PUU-X/2012”.Wacana, 16, 33 (2014): 4959.

Roth, Dikdan GedeSedana. "ReframingTriHitaKarana: From 'Balinese Culture' to Politics”. The Asia Pacific Journal of Anthropology, 16, 2 (2015): 157-75. DOI: 10.1080/14442213.2014.994674.

Santos, Boventura de Sausa. "Law: A Map of Misreading towards a Postmodern Conception of Law”. Journal of Law and Society, 14, 3 (1987): 279-302. DOI: $10.2307 / 1410186$.

Setlight, Mercy M. M. "Penerapan Hukum Pidana Adat dalam Putusan Pengadilan di Wilayah Pengadilan Negeri Tahuna”. Lex et Societatis, 3, 4 (2015): 154-66.

Simarmata, Rikardo. "Pendekatan Positivistik dalam Studi Hukum Adat”. Mimbar Hukum, 30, 3 (2018): 465-89. DOI: 10.22146/ jmh.37512.

Simarmata, Rikardo. "The Enforceability of Formalised Customary Land Rights in Indonesia”. Australian Journal of Asian Law, 19, 2 (2019): 1-15.

Simbolon, Indira Juditka. "Peasant Women and Access to Land: Customary Law, State Law and Gender-based Ideology-The Case of Toba Batak (North Sumatera)”. Disertasi, University of Wageningen, Wageningen, 1988.

Siscawati, Mia. "Pertaruangan Penguasaan Hutan dan Perjuangan Perempuan Adat”. Wacana, 16, 33 (2014): 159-97.

Sulastriyono dan Sandra Dini Febri Aristya. "Penerapan Norma dan Asas-Asas Hukum Adat dalam Praktik Peradilan Perdata”. Mimbar Hukum, 24, 1 (2012): 25-40. DOI: 10.22146/jmh.16147.

Sulastriyono dan Sartika Intaning Pradhani. "Pemikiran Hukum Adat Djojodigoeno dan Relevansinya Kini”. Mimbar Hukum, 30, 3 (2018): 449-64.DOI: 10.22146/jmh.36956.

Sumardjono, Maria S. W. Pluralisme Hukum Sumber Daya Alam dan Keadilan dalam Pemanfaatan Tanah Ulayat. Yogyakarta: Fakultas Hukum Universitas Gadjah Mada, 2018.

Universitas Gadjah Mada, Pusat Kajian Hukum adat 'Djojodigoeno’ 
Fakultas Hukum, dan Koalisi Masyarakat Sipik Tolak Living Law dalam RKUHP. Brief Paper: Hukum yang Hidup dalam Rancangan Undang-Undang Kitab Undang-Undang Hukum Pidana. Jakarta: Yayasan Lembaga Bantuan Hukum Indonesia \& Pusat Kajian Hukum Adat 'Djojodigoeno' Fakultas Hukum Universitas Gadjah Mada, 2020.

Utama, Tody Sasmitha Jiwa. "Hukum yang Hidup dalam Rancangan Kitab Undang-Undang Hukum Pidana (KUHP): antara Akomodasi dan Negasi”. Masalah-Masalah Hukum, 49, 1 (2020): 14-25. DOI: 10.14710/mmh.49.1.2020.14-25.

Utama, Tody Sasmitha Jiwa. "Masyarakat Hukum Adat: Persekutuan Hukum (Rechtsgemeenschappen) atau Subjek Hukum?”. Makalah Simposium Nasional Masyarakat Adat II, diselenggarakan Epistema Institute, Aliansi Masyarakat Adat Nusantara (AMAN), Perkumpulan HuMa, Pusat Kajian Hukum Adat Djojodigoeno Universitas Gadjah Mada, Komisi Nasional Hak Asasi Manusia, Fakultas Hukum Universitas Pancasila, Jaringan Kerja Pemetaan Partisipatif, dan Badan Registrasi Wilayah Adat, di Universitas Pancasila, Jakarta, 16-17/5/2016.

Utama, Tody Sasmitha Jiwa dan Sandra Dini Febri Aristya. "Kajian tentang Relevansi Peradilan Adat terhadap Sistem Peradilan Perdata Indonesia”. Mimbar Hukum, 27, 1 (2015): 57-67. DOI: 10.22146/jmh.15910.

Vel, Jacqueline, Yando Zakaria, Adriaan Bedneer. "Law-Making as a Strategy for Change: Indonesia’s New Village Law. Asian Journal of Law and Society, 4, 2 (2017): 447-71. DOI: 10.1017/ als.2017.21.

Volenhoven, C. Van. Penemuan Hukum Adat. Jakarta: Penerbit Djambatan, cetakan kedua, 1987.

Vollenhoven, C. van. Van Vollenhoven on Indonesian Adat Law Selection from Het Adatrecht Van Nederlandsch-Indie (Volume I, 1918; Volume II, 1931), diedit oleh J. F. Holleman. Leiden: KITLV, 1981.

Warman, Kurnia. "Pengaturan Sumberdaya Agraria pada Era Desentralisasi Pemerintahan di Sumatera Barat (Interaksi Hukum Adat dan Hukum Negara dalam Perspektif Keangekaragaman 
dalam Kesatuan Hukum). Disertasi, Universitas Gadjah Mada, Yogyakarta, 2009.

Zakaria, R. Yandi. "Kritik Masyarakat (Hukum) Adat dan Potensi Implikasinya terhadap Perebutan Sumberdaya Hutan PascaPutusan MK Nomor 35/PUU-X/2012: Studi Kasus Kabupaten Kutai Barat, Kalimantan Timur”. Wacana, 16, 33 (2014): 99-135. 